\title{
Spontaneous autopolyploidy in the Acipenseriformes, with recommendations for management
}

\author{
Andrea D. Schreier (D) J Joel P. Van Eenennaam • Paul Anders • \\ Shawn Young $\cdot$ Jamie Crossman (i)
}

Received: 25 June 2020/Accepted: 8 January 2021 / Published online: 15 February 2021

(C) The Author(s) 2021

\begin{abstract}
Sturgeon and paddlefishes (Acipenseriformes) are cultured worldwide for commercial and conservation purposes. Over the past decade, we have learned many sturgeon culture programs experience spontaneous autopolyploidy, or the generation of triploidy without management intervention. Spontaneous autopolyploidy has been shown to negatively impact the physiology, reproductive development and fertility of sturgeon. Given these concerns, it is necessary to understand how it arises, how it affects production, and how it can be managed. The goal of this review is to describe the incidence of spontaneous autopolyploidy in sturgeon relative to other fishes, explain how spontaneous autopolyploids are formed, and report what is known about how triploidy and
\end{abstract}

A. D. Schreier $(\varangle) \cdot$ J. P. Van Eenennaam

Department of Animal Science, University of California Davis, 2235 Meyer Hall, One Shields Ave, Davis, CA 95616, USA

e-mail: amdrauch@ucdavis.edu

P. Anders

Cramer Fish Sciences, 121 S. Jackson Street, Moscow, ID, USA

\section{S. Young}

Kootenai Tribe of Idaho, PO Box 1269, Bonners Ferry, ID, USA

J. Crossman

Fish and Aquatics, BC Hydro, 60118 Street, Castlegar, BC V1N 2N1, Canada intermediate ploidy effect sturgeon reproductive development and physiology. We then describe four common methods for detecting spontaneous autopolyploids and their intermediate ploidy progeny and end with recommendations for reducing the incidence of spontaneous autopolyploidy based on the results of recent research. Although spontaneous autopolyploidy may never be completely eliminated from sturgeon culture, following these recommendations may significantly decrease its incidence.

Keywords Acipenseriformes - Spontaneous autopolyploidy $\cdot$ Sturgeon $\cdot$ Triploidy $\cdot$ Egg quality

\section{Introduction}

The Acipenseriformes are large-bodied, long-lived sturgeons and paddlefishes that are captively propagated for commercial (meat and caviar; Bronzi et al. 2019) or conservation purposes (Hildebrand et al. 2016). Captive propagation of sturgeons, whatever the goal, is complicated by the species' tendency to experience spontaneous autopolyploidy in a culture environment (Schreier et al. 2013; Gille et al. 2015). Spontaneous autopolyploids possess an additional chromosome set (genome size 1.5 times larger) and are referred to as "spontaneous" because they arise in culture without any intentional management action to 
produce them. Although spontaneous autopolyploidy has been documented in wild sturgeon (see Spontaneous Autopolyploidy in Sturgeons), it seems to occur only rarely. Spontaneous autopolyploidy is a concern in sturgeon propagation because these fishes are genetic triploids and triploidy can impact growth, physiology, reproductive development and fertility. Although many triploid fishes are functionally sterile, spontaneous autopolyploids of at least some sturgeons are fertile and when crossed with normal adults can produce progeny of intermediate ploidy that, in white sturgeon (Acipenser transmontanus), exhibit reproductive abnormalities. Impaired performance or reproductive development of spontaneous autopolyploids and their progeny can reduce productivity of commercial farms and hinder recovery of populations supplemented by conservation aquaculture. Alternatively, fertile triploid females likely produce larger eggs than normal fish (Hardie and Hebert 2003; Smith and Gregory 2009), a trait valued by caviar farmers. For this reason, spontaneous autoploidy has become an important issue for commercial and conservation producers over the past several years.

Here, we review what is currently known about polyploidy and spontaneous autopolyploidy in sturgeons and paddlefishes, using reported instances of spontaneous autopolyploidy in other fishes to provide context. We discuss the causes of spontaneous autoploidy in culture and describe how it might affect commercial or conservation aquaculture programs. We end by providing practical recommendations for how to detect individuals of abnormal ploidy currently within captive stock or wild populations and how culture practices may be altered to reduce the incidence of spontaneous autopolyploidy.

\section{Biology}

Polyploidy in sturgeons

Although all fishes have experienced at least two whole genome duplications (WGDs) in their evolutionary history (Meyer and Van De Peer 2005), sturgeons and paddlefishes have undergone additional, lineage specific WGDs. All sturgeons and paddlefishes descend from a common ancestor possessing 60 chromosomes (Dingerkus and Howell 1976) and can be classified into three ploidy groups: those possessing 120 (Group A), 240 (Group B), or $\sim 360$ chromosomes (Group C; Birstein and Vasiliev 1987; Birstein et al. 1993; Blacklidge and Bidwell 1993; Kim et al. 2005). Ploidy of sturgeons and paddlefishes can be classified by total genome size, which reflects the evolutionary legacy of the lineage-specific WGD, or by functional ploidy, based on the level of diploidization observed in that group. Group A species had been classified as evolutionary tetraploids and functional diploids because they have experienced one Acipenseriformes specific WGD but seemed to exhibit only residual tetrasomy (Ludwig et al. 2001; Romanenko et al. 2015). However, genome sequencing of the Group A sterlet (Acipenser ruthenus) revealed a high degree of duplicate gene retention $(\sim 70 \%)$, indicating the label of "functional diploid" is inappropriate for this species (Du et al. 2020). Classification of functional ploidy is even less straightforward for species in Groups B and C because they exhibit varying degrees of polysomic inheritance of neutral genetic markers (Rodzen and May 2002; Drauch Schreier et al. 2011; King et al. 2014). Group $\mathrm{B}$ and $\mathrm{C}$ species are evolutionary octoploids $(8 \mathrm{~N})$ and dodecaploids $(12 \mathrm{~N})$, respectively, but their progression along the path to diploidization is uncertain and likely differs among species originating from different WGDs. Although five unique WGDs were proposed by Peng et al. (2007), the discovery that the Huso dauricus and Acipenser mikadoi genomes were octoploid (Zhou et al. 2011) reduces the most likely number of WGDs to three (Vasil'ev et al. 2010).

Spontaneous autopolyploidy in sturgeons

Although the most recent Acipenseriformes specific WGD occurred $<50$ million years ago (Peng et al. 2007), modern day WGD is occurring in cultured Acipenseriformes in the form of spontaneous autopolyploidy. Spontaneous autopolyploidy is not unique to the Acipenseriformes and has been reported in other fishes, although the phenomenon is generally considered rare (Table 1). Spontaneous autopolyploidy has been reported in the Otophysan fishes (Cypriniformes, Characiformes, Gymnotiformes, and Siluriformes) as well as in the Salmoniformes, which are also known to have experienced a lineage specific WGD (Table 1). However, spontaneous autopolyploidy appears to occur more frequently in the Acipenseriformes than in any other single lineage 
Table 1 Incidences of spontaneous autopolyploidy (spontaneous triploidy) in otherwise diploid fishes reported in the English literature

\begin{tabular}{|c|c|c|c|c|}
\hline Species & $\begin{array}{l}\text { Method } \\
\text { (s) }\end{array}$ & Origin & $\begin{array}{l}\text { Prop. } \\
\text { detected }\end{array}$ & References \\
\hline \multicolumn{5}{|l|}{ Cartilaginous fishes } \\
\hline Nurse shark (Ginglymostoma cirratum) & $\mathrm{FC}$ & $\mathrm{W}$ & $1 / 7$ & Kendall et al. (1994) \\
\hline \multicolumn{5}{|l|}{ Bony fishes } \\
\hline \multicolumn{5}{|l|}{ Characiformes } \\
\hline Astyanax sp. & $\mathrm{K}$ & $\mathrm{W}$ & $1 / 7$ & Kantek et al. (2007) \\
\hline Astayanx eigenmanniorum & $\mathrm{K}$ & $\mathrm{W}$ & $2 / 30$ & Fauaz et al. (1994) \\
\hline \multirow[t]{4}{*}{ Banded astyanax (Astyanax scabripinnis) } & $\mathrm{K}$ & $\mathrm{W}$ & $1 / 74$ & Fauaz et al. (1994) \\
\hline & $\mathrm{K}$ & $\mathrm{W}$ & $2 / 40$ & Maistro et al. (1994) \\
\hline & $\mathrm{K}$ & $\mathrm{W}$ & $1 / 5$ & Cristina et al. (2003) \\
\hline & $\mathrm{K}$ & $\mathrm{W}$ & $1 / 73$ & Machado et al. (2012) \\
\hline Canivete (Characidium gomesi) & $\mathrm{K}$ & $\mathrm{W}$ & $1 / 27$ & Centofante et al. (2001) \\
\hline Curimata modesta & $\mathrm{K}$ & $\mathrm{W}$ & $1 / 10$ & Venere and Galetti Junior (1985) \\
\hline Lambari (Asyanax schubarti) & $\mathrm{K}$ & $\mathrm{W}$ & $1 / 21$ & Morelli et al. (1983) \\
\hline Megaleporinus elongatus & $\mathrm{K}$ & $\mathrm{W}$ & $1 / 28$ & Molina et al. (2007) \\
\hline Wolf fish (Hoplias malabaricus) & $\mathrm{K}$ & $\mathrm{W}$ & $1 / 17$ & Utsunomia et al. (2014) \\
\hline \multicolumn{5}{|l|}{ Cypriniformes } \\
\hline California roach (Lavinia symmetricus) & $\mathrm{K}$ & $\mathrm{W}$ & $1 / 9$ & Gold and Avise (1976) \\
\hline Bighead carp (Hypophthalmichthys nobilis) & $\mathrm{FC}$ & $\mathrm{C}$ & $1 / 38$ & Allen and Stanley (1983) \\
\hline \multirow[t]{2}{*}{ Common carp (Cyprinus carpio) } & $\mathrm{K}$ & $\mathrm{C}$ & $1 / ?$ & Al Sabti et al. (1983) \\
\hline & $\mathrm{CC}, \mathrm{FC}$ & $\mathrm{C}$ & $1 / 248$ & Gomelsky et al. (2015) \\
\hline Grass carp (Ctenopharyngodon idella) & $\mathrm{FC}$ & $\mathrm{C}$ & $1 / 38$ & Allen and Stanley (1983) \\
\hline Fathead minnow (Pimephales promelas) & BS & $\mathrm{W}$ & $1 / 15$ & Gold (1986) \\
\hline \multirow{3}{*}{$\begin{array}{l}\text { Oriental weatherfish (Misgurnus } \\
\text { anguillicaudatus) }\end{array}$} & $\mathrm{K}, \mathrm{BS}$ & $\mathrm{W}$ & $1 / 80$ & Ojima and Takai (1979) \\
\hline & $\mathrm{FC}$ & $\mathrm{W}$ & $23 / 1,815$ & Zhang and Arai (1999) \\
\hline & $\mathrm{FC}, \mathrm{K}, \mathrm{BS}$ & $\mathrm{W}$ & $1 / 41$ & Abbas et al. (2009) ${ }^{\mathrm{a}}$ \\
\hline Tench (Tinca tinca) & BS & $\mathrm{C}$ & $26 / 107$ & Flajshans et al. (1993) \\
\hline Weatherfish (Misgurnus fossilis) & $\mathrm{FC}, \mathrm{BS}$ & & $19 / 116$ & Drozd et al. (2010) \\
\hline \multicolumn{5}{|l|}{ Gymnotiformes } \\
\hline Banded knifefish (Gymnotus carapo) & $\mathrm{K}$ & $\mathrm{W}$ & $1 / 17$ & Fernandes-Matioli et al. (1998) \\
\hline Eigenmannia sp. & $\mathrm{K}$ & $?^{\mathrm{b}}$ & $1 / 6$ & De Almeida Toledo et al. (1985) \\
\hline \multicolumn{5}{|l|}{ Salmoniformes } \\
\hline \multirow[t]{2}{*}{ Atlantic salmon (Salmo salar) } & MG & $\mathrm{C}$ & $47 / 111$ & Ozerov et al. (2010) \\
\hline & $\mathrm{FC}, \mathrm{MG}$ & $\mathrm{C}$ & $91 / 5,051$ & Glover et al. (2015) \\
\hline Coho salmon (Oncorhynchus kisutch) & $\mathrm{FC}$ & $\mathrm{C}$ & $5 / 1,560$ & Devlin et al. (2010) \\
\hline \multirow[t]{6}{*}{ Rainbow trout (Oncorhynchus mykiss) } & $\mathrm{K}$ & $\mathrm{C}$ & $1 / 18$ & Cuellar and Uyeno (1972) \\
\hline & $\mathrm{K}$ & $?$ & $1 / 34$ & $\begin{array}{l}\text { Grammeltvedt (1974), cited in Benfey } \\
\text { (1989) }\end{array}$ \\
\hline & $\mathrm{K}, \mathrm{BS}$ & $\mathrm{C}$ & $6 / 79$ & Thorgaard and Gall (1979) \\
\hline & $\mathrm{FC}$ & $\mathrm{C}$ & $2 / 30^{\mathrm{c}}$ & Thorgaard et al. (1982) \\
\hline & $\mathrm{K}$ & $\mathrm{C}$ & $2 / 17$ & Ueda et al. (1983) \\
\hline & $\mathrm{K}$ & $\mathrm{C}$ & $3 / 21$ & Ueda et al. (1987) \\
\hline Sockeye salmon (Oncorhynchus nerka) & $?$ & $\mathrm{~W}$ & $18 / 117$ & Chernenko (1968), cited in Benfey (1989) \\
\hline
\end{tabular}


Table 1 continued

\begin{tabular}{lllll}
\hline Species & $\begin{array}{l}\text { Method } \\
(\mathrm{s})\end{array}$ & Origin & $\begin{array}{l}\text { Prop. } \\
\text { detected }\end{array}$ & References \\
\hline $\begin{array}{l}\text { Siluriformes } \\
\text { Indian catfish (Heteropneustes fossilis) }\end{array}$ & K, BS & W & $5 / 120$ & Pandian and Koteeswaran (1999) \\
Rhamdia quelen & K & W & $1 / 5$ & Tsuda et al. (2010) \\
Three-barbeled catfish (Rhamdia sp.) & K & W & $1 / 13$ & Garcia et al. (2003) \\
Trichomycterus davisi & K & W & $1 / 50$ & Borin et al. (2002) \\
\hline
\end{tabular}

Only instances where autopolyploidy was known not to be caused by human intervention are included. Under methods, BS is blood smear analysis, CC is Coulter counter, FC is flow cytometry, $\mathrm{K}$ is karyotyping, and MG is microsatellite genotyping. C refers to individuals in captivity and $\mathrm{W}$ refers to individuals captured in the wild. Prop. detected is the proportion of spontaneous autopolyploids reported in a study

${ }^{a}$ The individual reported here was a spontaneous autopolyploid produced by tetraploid parents (naturally occurring diploids and tetraploids have been reported for this species)

borigin is unclear; specimens were acquired from a "specialized animal dealer" but could have been captured in the wild

${ }^{c} 30$ individuals with delayed sexual maturity sampled out of 1,130 fish total

(Table 2). In some sturgeon species, such as white sturgeon (Acipenser transmontanus), numerous spontaneous autopolyploid individuals have been documented (Table 2). It is not known why spontaneous autopolyploidy is so prevalent in the Acipenseriformes but their already polyploid genomes may make them better able to cope with additional genome copies relative to fully diploidized taxa.

Spontaneous autopolyploidy has been best studied in cultured white sturgeon. Normal white sturgeon are Group B evolutionary octoploids (8N) and their spontaneous autopolyploids are dodecaploid (12N). The incidence of spontaneous autopolyploidy in cultured white sturgeon varies by maternal family and in the absence of experimental manipulation, can range from 0 to $>90 \%$ (Schreier et al. 2013; Gille et al. 2015).

Although the vast majority of sturgeon spontaneous autopolyploids have been detected in culture, some wild spontaneous autopolyploid white sturgeon have been reported. Ploidy screening of subadult and adult white sturgeon in the Sacramento-San Joaquin drainage $(n=8)$ and Hells Canyon reach of the Snake River $(n=136)$, and the Upper Columbia River $(n=31)$ revealed no spontaneous autopolyploids, but in the Kootenai and Lower Columbia Rivers, one and two wild adults, respectively, have been detected .
Because of the size and presumed age of the spontaneous autopolyploid adults found the Lower Columbia and Kootenai rivers, they could not have originated from conservation aquaculture which started in the 1990s. From these data we hypothesize that spontaneous autopolyploidy occurs at some background level in the wild but only a very small proportion of naturally produced spontaneous autopolyploids survive outside of a hatchery environment. This hypothesis is consistent with the majority of observations of spontaneous autopolyploidy in other fishes (Table 1). Small numbers of triploid individuals are detected in wild populations and likely form due to natural processes.

\section{Causes of spontaneous autopolyploidy in sturgeons}

Natural processes known to cause fish spontaneous autopolyploidy are polyspermy and retention of the egg's second polar body during meiosis II. Polyspermy refers to the fertilization of an egg by multiple sperm. In some species, such as chondrichthyan fishes, amphibians, reptiles, birds, and some insects, multiple sperm normally penetrate the egg but only one sperm fuses with the maternal pronucleus (physiological polyspermy; Jaffe and Gould 1985). Eggs of 
Table 2 Instances of spontaneous autopolyploidy documented in sturgeon

\begin{tabular}{|c|c|c|c|c|}
\hline Species & $\begin{array}{l}\text { Method } \\
\text { (s) }\end{array}$ & Origin & Prop. detected & References \\
\hline $\begin{array}{l}\text { Atlantic sturgeon (Acipenser oxyrinchus } \\
\text { oxyrinchus) }\end{array}$ & $\mathrm{FC}, \mathrm{CC}$ & $\mathrm{CA}$ & $8 / 42$ & $\begin{array}{l}\text { Schreier and Van Eenennaam } \\
\text { ( 2016) }\end{array}$ \\
\hline Gulf sturgeon(Acipenser oxyrinchus desotoi) & FC & $\mathrm{RC}$ & $1 / 15$ & Blacklidge and Bidwell (1993) \\
\hline \multirow[t]{2}{*}{ Bester (Huso huso x Acipenser ruthenus) } & $\mathrm{FC}$ & $\mathrm{RC}$ & $\begin{array}{l}0-65 \% \text { across } 10 \\
\text { families }\end{array}$ & Omoto et al. (2005) \\
\hline & $\mathrm{FC}$ & $\mathrm{RC}$ & $1 / 10$ & Zhou et al. (2011) \\
\hline Kaluga (Huso dauricus) & $\mathrm{FC}$ & $\mathrm{RC}$ & $3 / ?$ & Zhou et al. (2011) \\
\hline \multirow[t]{4}{*}{ Lake sturgeon (Acipenser fulvescens) } & $\mathrm{FC}$ & $\mathrm{CA}$ & $1 / 8$ & Blacklidge and Bidwell (1993) \\
\hline & $\mathrm{MG}^{\mathrm{a}}$ & $\mathrm{CA}$ & $\sim 21 / 419^{b}$ & Pyatskowit et al. (2001) \\
\hline & $\mathrm{MG}^{\mathrm{a}}$ & $\mathrm{CA}$ & $\sim 7 / 300$ & McQuown et al. (2002) \\
\hline & $\mathrm{MG}^{\mathrm{a}}$ & $\mathrm{CA}$ & $\sim 1 / 212$ & Welsh and May (2006) \\
\hline Russian sturgeon (Acipenser gueldenstaedtii) & $\mathrm{FC}, \mathrm{BS}$ & $\mathrm{RC}$ & $3 / ?$ & Bytyutskyy et al. (2012) \\
\hline \multirow[t]{2}{*}{ Sakhalin sturgeon (Acipenser mikadoi) } & $\mathrm{K}$ & $\mathrm{U}^{\mathrm{c}}$ & $4 / 4$ & Birstein et al. (1993) \\
\hline & $\mathrm{FC}$ & $\mathrm{RC}$ & $62 / 137$ & Zhou et al. (2011) \\
\hline \multirow[t]{5}{*}{ Siberian sturgeon (Acipenser baerii) } & FC & $\mathrm{CF}^{\mathrm{d}}$ & $2 / 10$ & Zhou et al. (2011) \\
\hline & $?$ & $\mathrm{RC}$ & $1 / ?$ & Pšenička et al. (2011) \\
\hline & $\mathrm{FC}, \mathrm{BS}$ & $\mathrm{RC}$ & $2 / ?$ & Bytyutskyy et al. (2012) \\
\hline & $\mathrm{FC}, \mathrm{K}, \mathrm{BS}$ & $\mathrm{RC}$ & $2 / 8$ & Havelka et al. (2014) \\
\hline & $\mathrm{FC}, \mathrm{K}, \mathrm{BS}$ & $\mathrm{RC}$ & $7 / 143^{\mathrm{e}}$ & Havelka et al. (2016) \\
\hline \multirow[t]{2}{*}{ Sterlet (Acipenser ruthenus) } & FC & $\mathrm{CF}, \mathrm{RC}^{\mathrm{f}}$ & $1 / 12$ & Zhou et al. (2011) \\
\hline & FC, MG & $\mathrm{RC}$ & $6 / 110$ & Havelka et al. (2013) \\
\hline \multirow[t]{5}{*}{ White sturgeon (Acipenser transmontanus) } & $\mathrm{FC}$ & $\mathrm{CF}$ & $1 / 812 \mathrm{~N}, 146 / 72610 \mathrm{~N}$ & Drauch Schreier et al. (2011) \\
\hline & FC & $\mathrm{RC}$ & $1 / 11$ & Zhou et al. (2011) \\
\hline & $\mathrm{FC}$ & $\mathrm{CA}$ & $12 / 138$ & Schreier et al. (2013) \\
\hline & $\mathrm{FC}$ & $\mathrm{CF}, \mathrm{CA}$ & $20 / 284$ & Gille et al. (2015) \\
\hline & $\mathrm{FC}, \mathrm{C}$ & $\mathrm{CF}, \mathrm{CA}$ & $85 / 124^{\mathrm{g}}$ & Fiske et al. (2019) \\
\hline
\end{tabular}

Only instances where autopolyploidy was known to be spontaneous are included. FC is flow cytometry, $\mathrm{K}$ is karyotyping, BS is blood smear analysis (including Feulgen densitometry), MG is microsatellite genotyping. CF refers to commercial farm, CA refers to conservation aquaculture, and RC refers to fish in university research collections. U refers to fish of unknown origin. Prop. detected is the proportion of spontaneous autopolyploids reported in a study

${ }^{a}$ Three alleles present at otherwise disomic loci in several individuals

${ }^{\mathrm{b}}$ Based on numbers of progeny presented in Table 6 of Pyatskowit et al. (2001)

${ }^{\mathrm{c}}$ Birstein et al. (1993) report four Sakhalin sturgeon with a DNA content of 13.93-14.73 pg and 500 chromosomes observed via karyotyping. Based on what we know about Sakhalin sturgeon genome size, these individuals were likely spontaneous autopolyploids. The origin of these fish was the Moscow Aquarium but it is unknown if these fish were born in captivity or wild caught

${ }^{\mathrm{d}}$ Individuals originated from a commercial aquarium shop

${ }^{\mathrm{e}}$ The seven individuals are not triploid but represent spontaneous autopolyploids resulting from cross of $8 \mathrm{Nand} 12 \mathrm{~N}$ parents (14N)

${ }^{\mathrm{f}}$ Individuals originated from a commercial aquarium shop or the Bifuko Sturgeon Museum

${ }^{\mathrm{g}}$ Families with high and low proportions of spontaneous autopolyploids were selected for study 
osteichthyan fishes can only accommodate a single sperm and have evolved several defenses against polyspermy. First, penetration of sperm into sturgeon and teleost eggs is limited to micropyles, or small channels in the chorion that permit sperm entry. While some fishes have only one micropyle (i.e. most teleosts; Jaffe and Gould 1985), sturgeon have multiple micropyles per egg (Dettlaff et al. 1993), theoretically allowing multiple sperm to enter. Multiple sperm rarely enter sturgeon eggs because of another defense against polyspermy, the cortical reaction. When the first sperm penetrates the egg, cortical granules, or mucopolysaccharide containing granules found in the cytoplasm of the egg, fuse with the plasma membrane and begin to break down (Gilkey 1981). The granule breakdowns start nearest the micropyle of sperm entry and spread outwards, causing the plasma membrane to separate from the cytoplasm (Ginsburg 1961; Gilkey 1981; Psenicka et al. 2010). The discharged contents of the cortical granules prevent any additional spermatozoa entering other micropyles from penetrating the cytoplasm (Dettlaff et al. 1993).

Although polyspermy has been documented in sturgeon, it usually occurs only when sperm concentrations are very high. Even at high sperm concentrations, only a small proportion of embryos are polyspermic $(<10 \%$; Cherr and Clark 1985). Early reports indicated that polyspermic embryos died early in development (Dettlaff et al. 1993), and aquaculture programs dilute their sperm to reduce polyspermy (1:200; Van Eenennaam et al. 2004). The only surviving polyspermic sturgeon reported are mosaics, or individuals composed of cells of differing ploidy (Iegorova et al. 2018a, b). Because spontaneous autopolyploids are uniformly triploid, polyspermy is unlikely to be the cause of spontaneous autopolyploidy in sturgeon.

Second polar body retention occurs when a physical, chemical, or pressure shock disrupts ejection of the second polar body during meiosis (Piferrer et al. 2009). Retention of the second polar body is the mechanism by which genetic triploidy is intentionally induced in cultured fishes. The fact that spontaneous autopolyploidy varies by maternal rather than paternal family suggests that second polar body retention is the cause of spontaneous autopolyploidy in sturgeons. A study of how unique maternal and paternal microsatellite alleles are transmitted in white sturgeon families containing $8 \mathrm{~N}$ and $12 \mathrm{~N}$ progeny showed that $12 \mathrm{~N}$ white sturgeon inherit more maternal than paternal allele copies (Gille et al. 2015), consistent with second polar body retention as the cause of spontaneous autopolyploidy. Recent experiments have investigated two potential causes of second polar body retention in sturgeon aquaculture, post-ovulatory ageing and mechanical shock (Van Eenennaam et al. 2020).

\section{Causes of second polar body retention}

Post-ovulatory ageing refers to changes that occur in eggs between the onset of ovulation and fertilization and has been implicated in spontaneous autopolyploidy in many fishes: the hybrid sturgeon bester (Huso huso $\times$ Acipenser ruthenus; Omoto et al. 2005), tench (Tinca tinca; Flajshans et al. 1993; Flajšhans et al. 2007), European catfish (Siluris glanis; Várkonyi et al. 1998), rainbow trout (Oncorhynchus mykiss; Aegerter and Jalabert 2004), farmed Atlantic salmon (Salmo salar; Glover et al. 2015), and yellowtail tetra (Astyananx altiparanae; Pereira dos Santos et al. 2018). In a hatchery setting, post-ovulatory ageing can occur in vitro (outside the body cavity) or in vivo (within the abdomen of a female). In vitro ageing is seldom a problem for sturgeon hatcheries as collected eggs are routinely fertilized in a timely fashion (within 15 min). However, in vivo ageing may occur when there are multiple females being spawned on one day and oviposition begins in more than one fish at approximately the same time. A female that is ready for egg collection but cannot be processed until several hours later has potentially undergone post-ovulatory ageing. In vivo ageing may also occur if the first oviposition is missed and egg collection unknowingly occurs well after ovulation began.

Van Eenennaam et al. (2020) tested the hypothesis that post-ovulatory ageing causes sturgeon spontaneous autopolyploidy using progeny from four white sturgeon females at a California caviar farm. Eggs from each female were aged in vitro for 6-7 h before fertilization or fertilized at the industry normative time (3-4 h post-ovulation; controls) and progeny from both groups were screened for ploidy. They found little difference between progeny from control and in vitro aged eggs for three females, while the fourth female exhibited twice as many spontaneous autopolyploids after the ageing treatment $(5.5 \%$ 
control to $11.3 \%$ aged eggs; Van Eenennaam et al. 2020). Later experiments combining in vitro ageing and other treatments including six additional females revealed higher rates of spontaneous autopolyploidy relative to farm controls in progeny from three females, similar rates in two females, and lower rates in one female (Van Eenennaam et al. 2020). The lack of a consistent association between ageing and spontaneous autopolyploidy indicates that post-ovulatory ageing is not the primary cause of second polar body retention in cultured sturgeon and implies that variable egg quality among females may affect the incidence of spontaneous autopolyploidy (Van Eenennaam et al. 2020).

Another mechanism that can contribute to spontaneous autopolyploidy is physical disturbance of the egg, or mechanical shock. In a culture setting, unintentional mechanical shock can occur during the de-adhesion process, when eggs are physically stirred in a bowl with silt to prevent them from clumping together and dying of anoxia. This de-adhesion treatment lasts for about $60 \mathrm{~min}$, beginning after two minutes of fertilization, and is within the time window in which meiosis II is completed in sturgeon and the second polar body is typically ejected (12-20 min post-fertilization; Van Eenennaam et al. 1996; Flynn et al. 2006; Fopp-Bayat 2010). A recent experiment compared the effect of "vigorous" and "gentle" stirring treatments during de-adhesion on batches of eggs from white sturgeon caviar farms in Idaho and California. The "vigorous" treatment involved a constant back and forth, swirling, mixing of eggs using a feather, while the "gentle" treatment involved an occasional (every $10 \mathrm{~s}$ ) slow and gentle folding of eggs from along the bottom of the bowl to the surface using a feather. The proportion of spontaneous autopolyploid progeny ranged from 0 to $52 \%$ (median $0 \%$ ) in the "gentle" treatments to $1.3-80 \%$ (median $8.35 \%$ ) in the "vigorous" treatments (Van Eenennaam et al. 2020). Although the exact mechanism behind mechanical shock is unknown, it is hypothesized that the force of the eggs colliding with each other, the side of the bowl, and the mixing tool somehow disrupt the spindle apparatus and result in second polar body retention (Van Eenennaam et al. 2020).

There is also some evidence that genetic background may influence the incidence of spontaneous autopolyploidy in sturgeons and other fishes. A study of common carp (Cyprinus carpio) provided preliminary evidence that the propensity for second polar body retention may be a heritable trait (Cherfas et al. 1995), and studies in salmonids have shown that females' eggs can be more or less susceptible to triploidization (Johnson et al. 2004; Devlin et al. 2010). Van Eenennaam et al. (2020) spawned the same female white sturgeon in both 2017 and 2019 and detected a high incidence of spontaneous autopolyploidy in the experimental treatment ("vigorous" stirring) for each spawn (80 and 64\%, respectively). Additional research with more females is required to test the hypothesis that certain females have a genetic propensity to produce spontaneous autopolyploid progeny.

\section{Effects of triploidy on sturgeons}

One of the best known effects of triploidization on cultured fishes is sterilization (Piferrer et al. 2009), although male or female triploids may retain fertility in some species (Lincoln 1981a; Benfey et al. 1986; Feindel et al. 2010; Gomelsky et al. 2015). Omoto et al. (2005) found that spontaneous autopolyploid female bester exhibited arrested oogenesis in culture, even at age-11. A similar case of female sterility was reported for induced triploid bester (Omoto et al. 2002). Preliminary data suggest that spontaneous autopolyploid female Atlantic sturgeon (Acipenser oxyrinchus oxyrinchus), another Group A species, may also exhibit delayed reproductive maturity (Schreier and Van Eenennaam 2016). Although further study is needed, reproductive abnormalities in Group A species may be due to unbalanced chromosome pairing at meiosis in disomically inherited regions of the genome, similar to what is observed in diploid fishes.

A few studies have investigated the effect of spontaneous autopolyploidy and induced triploidy on Group B species. In Group B, both male and female spontaneous autopolyploids (12Ns) are fertile and when crossed with diploid $(8 \mathrm{~N})$ conspecifics produce viable progeny of intermediate ploidy $(10 \mathrm{~N}$; white sturgeon, Drauch Schreier et al. 2011; Siberian sturgeon, Acipenser baerii, Havelka et al. 2014, 2016). Unlike Group A spontaneous autopolyploids, which would produce gametes with 3 chromosome sets each, in Group B gametes have an even number of chromosomes (6 chromosome sets each) 
which could explain normal fertility. However, preliminary work has revealed that female $10 \mathrm{~N}$ white sturgeon (age 6 years) exhibit delayed reproductive development relative to age-matched diploids (Schreier et al. 2020). No comparative study on the gametogenesis of spontaneous autopolyploid sturgeon has been conducted. A multi-year study of harvested females at a California caviar farm, including 27 spontaneous autopolyploids, 22 10Ns, and 149 diploids showed that spontaneous autopolyploids and $10 \mathrm{Ns}$ tended to have fattier ovaries than diploids with 10Ns exhibiting the fattiest ovaries and lowest caviar yield (Schreier et al. 2019).

Several studies have evaluated blood composition of diploid and triploid sturgeons. As documented in numerous animal triploids (Abdel-Hameed and Neat 1972; Small and Benfey 1987; Gao et al. 2007), erythrocytes of induced triploid shortnose sturgeon (Acipenser brevirostrum), 10N white sturgeon, and spontaneous autopolyploid white sturgeon were larger than those of diploids and fewer in number (Fig. 1; Beyea et al. 2005; Leal et al. 2018, 2019, 2020). The difference in size and abundance of erythrocytes between diploids and triploids is significant because having fewer, larger cells with a lower surface area to volume (SA:V) ratio can impact oxygen carrying capacity and hemoglobin concentration. Although the mean erythrocytic hemoglobin, a measure of the amount of hemoglobin per cell, was higher in induced triploid shortnose and spontaneous autopolyploid white sturgeon, the total amount of hemoglobin measured in blood was the same or lower than that of diploids (Beyea et al. 2005; Leal et al. 2019, 2020). Higher mean erythrocytic hemoglobin with similar levels of total hemoglobin have been reported in induced triploid relative to diploid shi drum (Umbrina cirrosa) and Caspian salmon (Salmo trutta) (Ballarin et al. 2004; Dorafshan et al. 2008).

Relative to other fishes, particularly salmonids, there are few studies examining the effect of triploidy on performance of sturgeon in aquaculture. In other fishes, triploidy has been shown to increase or decrease growth and survival, depending on the life stages investigated and whether diploids and triploids are reared separately or communally (Carter et al. 1994; Withler et al. 1995; Johnson et al. 2004, 2019; Cal et al. 2006; Chiasson et al. 2009; Taylor et al. 2011, 2014; Aussanasuwannakul et al. 2011; Fraser et al. 2013; Sacobie et al. 2016; Nuez-Ortín et al. 2017;
Liu et al. 2018; Janhunen et al. 2019). One explanation for the variable performance of triploids reported in the litereature is a lesser ability to handle stressful conditions such as elevated temperature or hypoxia (Ojolick et al. 1995; Atkins and Benfey 2008; Scott et al. 2014; Bowden et al. 2018; Lahnsteiner et al. 2019). Triploids may be more vulnerable to heat shocks than diploids because they possess lower levels of stress response proteins, less ability to recycle damaged proteins, and lower tolerance to apoptosis because they have fewer cells to begin with (Saranyan et al. 2017). The SA:V ratio in triploid erythrocytes and lower hemoglobin concentrations often observed
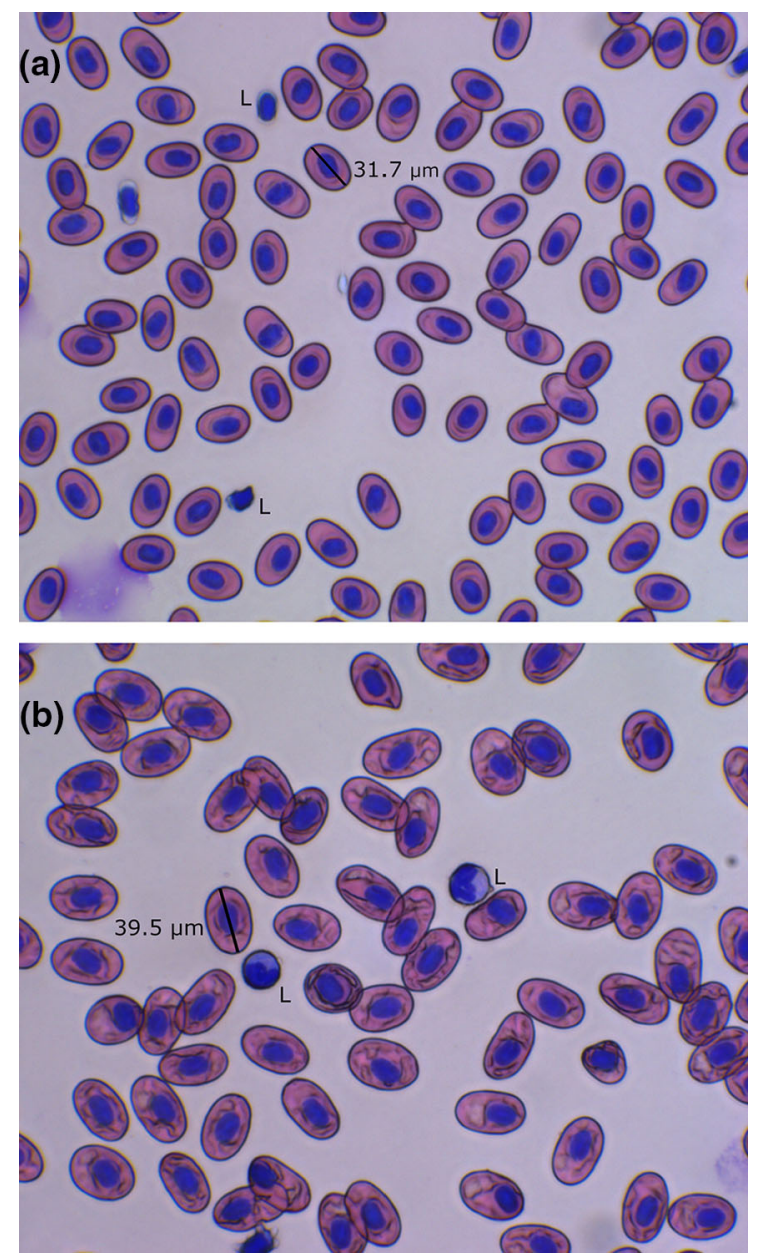

Fig. 1 Images of fixed and Wright Giemsa stained blood smears for a known diploid (8N) (a) and a known spontaneous autopolyploid $(12 \mathrm{~N})($ b) white sturgeon at $40 \times$ magnification. Long axis length of one mature erythrocyte, as measured in ImageJ (https://imagej.nih.gov/ij/), is indicated on each panel. The letter $\mathrm{L}$ indicates leukocytes 
in triploids could negatively impact oxygen carrying capacity, aerobic metabolic rate, and ability to adapt to stressful conditions (Bowden et al. 2018). Triploids also may use more oxygen under stressful conditions than diploids (Hansen et al. 2015), or they may simply be unable to switch from aerobic to anaerobic metabolism when exposed to hypoxic conditions (Scott et al. 2014).

Several studies have documented differences between diploid, triploid, and intermediate ploidy sturgeon in their responses to stress. In white sturgeon, $10 \mathrm{~N}$ individuals had significantly lower plasma cortisol concentrations before and after warming stress, although diploid and spontaneous autopolyploid white sturgeon and diploid and induced triploid shortnose sturgeon exhibited a similar stress response (Beyea et al. 2005; Leal et al. 2018, 2019, 2020). Plasma osmolality, chloride ion concentration, and plasma lactate levels were elevated in induced triploid shortnose sturgeon relative to diploids, suggesting chronic stress, although this was not observed in spontaneous autopolyploid white sturgeon (Beyea et al. 2005; Leal et al. 2019). Hemoglobin was found to increase with warming in spontaneous autopolyploid white sturgeon, possibly to compensate for reduced oxygen carrying capacity (Leal et al. 2019, 2020). One major difference between diploid, $10 \mathrm{~N}$, and spontaneous autopolyploid white sturgeon is the capacity to remodel cellular metabolism in response to stress (Leal et al. 2018, 2019). This inability to modulate cellular metabolism when stressed, along with a lowered erythrocyte SA:V ratio and less hemoglobin, may contribute to the lowered maximum metabolic rate and lowered aerobic scope observed in spontaneous autopolyploid juvenile white sturgeon relative to diploids after exhaustive exercise (Leal et al. 2020).

\section{Implications of spontaneous autopolyploidy for sturgeon culture programs}

The effect of spontaneous autopolyploidy on sturgeon culture programs will depend on the type of culture program. For commercial programs, the presence of a large number of intermediate ploidy sturgeon with lower caviar yields and delayed sexual maturity would reduce efficiency for producers of Group B species caviar. A lesser ability to adapt to stressful conditions, particularly high temperatures and hypoxia predicted to occur more frequently with climate change, could result in reduced growth for juvenile spontaneous autopolyploids, which would impact time to fillet harvest or time to sexual maturity for caviar harvest. Although spontaneous autopolyploid and intermediate ploidy females have been detected at several white sturgeon caviar farms, the numbers to date have not been sufficient to impact production .

Conservation aquaculture programs may not wish to release spontaneous autopolyploids that would produce female progeny with delayed fertility and reduced fecundity into vulnerable wild populations. Further, conservation programs are typically looking to maximize genetic diversity of supplemental progeny so production of families with elevated incidence of spontaneous autopolyploidy may result in reduced genetic diversity at the time of release into the wild. Another concern for conservation programs is that the progeny of spontaneous autopolyploid (Group A) and intermediate ploidy (Group B) sturgeon will be aneuploid. For example, a $6 \mathrm{~N}$ (triploid) Group A sturgeon would transmit three genome copies to progeny while a normal $4 \mathrm{~N}$ adult would transmit two, creating offspring with 5 genome copies. Although no research has been conducted on aneuploid sturgeon, aneuploids of other fish species are inviable due to unbalanced chromosome numbers (Lincoln 1981b; Peruzzi et al. 2009).

\section{Management}

Because of the negative effects that spontaneous autopolyploids and intermediate ploidy progeny can have on sturgeon culture programs, it is essential to address the risks with specific actions within program management plans. Below we review methods for detecting sturgeon of abnormal ploidy and provide a series of recommendations to minimize spontaneous autopolyploidy in culture programs.

\section{Detection of spontaneous autopolyploidy}

Four methods are currently available to detect spontaneous autopolyploidy in sturgeons and other fishes: karyotyping, flow cytometry, Coulter counter analysis, and blood smear analysis (Table 3). Karyotyping, or chromosome counting, directly measures chromosome number, the parameter upon which ploidy is 
Table 3 General pros and cons of the four available detection methods for spontaneous autopolyploidy

\begin{tabular}{|c|c|c|}
\hline $\begin{array}{l}\text { Detection } \\
\text { method }\end{array}$ & Pros & Cons \\
\hline Karyotyping & $\begin{array}{l}\text { - Direct way to determine the ploidy of an } \\
\text { individual fish } \\
\text { - Highly accurate if diploid chromosome } \\
\text { number is known }\end{array}$ & $\begin{array}{l}\text { - Requires significant technical expertise } \\
\text { - Chemicals required to arrest cellular division are toxic } \\
\text { - Time consuming }(>24 \mathrm{~h}) \\
\text { - Required sampling is lethal or requires cell culture } \\
\text { - Synaptonemal complex analysis limited to males because they } \\
\text { have an abundance of gametes in early stages of maturity }\end{array}$ \\
\hline $\begin{array}{l}\text { Flow } \\
\text { cytometry }\end{array}$ & $\begin{array}{l}\text { - Considered the "gold standard" technique for } \\
\text { indirect ploidy determination } \\
\text { - Highly accurate } \\
\text { - Requires no validation }\end{array}$ & $\begin{array}{l}\text { - Requires significant technical expertise } \\
\text { - Required DNA stains are toxic } \\
\text { - Time consuming } \\
\text { - Not best method of ploidy determination for facilities in remote } \\
\text { locations } \\
\text { - Variable quality of commercially available standards } \\
\text { - Requires }>25 \mathrm{~g} \text { fish for non-lethal blood sampling }\end{array}$ \\
\hline $\begin{array}{l}\text { Coulter } \\
\text { counter }\end{array}$ & $\begin{array}{l}\text { - Highly accurate ( } 100 \% \text { concordance with flow } \\
\text { cytometry) } \\
\text { - Required chemical solutions less toxic than } \\
\text { other methods } \\
\text { - Simplified sample transport and storage } \\
\text { requirements } \\
\text { - Simplified sample preparation } \\
\text { - Hundreds of samples run/day } \\
\text { - Only } 1-2 \mu \text { l blood required so small fish can } \\
\text { be non-lethally sampled }\end{array}$ & $\begin{array}{l}\text { - High cost of instrument } \\
\text { - Care required to standardize sample storage and analysis } \\
\text { conditions to ensure data reproducibility }\end{array}$ \\
\hline $\begin{array}{l}\text { Blood } \\
\text { smear }\end{array}$ & $\begin{array}{l}\text { - Requires least amount of equipment and } \\
\text { expertise of the four ploidy detection methods } \\
\text { - Only } 2-3 \mu \text { l blood required so small fish can } \\
\text { be non-lethally sampled } \\
\text { - No standard required }\end{array}$ & $\begin{array}{l}\text { - Lowest accuracy of the four methods (Fiske et al. 2019) } \\
\text { - Per-sample preparation and analysis time (15-20 min) is longer } \\
\text { than for Coulter counter analysis } \\
\text { - Requires validation with flow cytometry or Coulter counter } \\
\text { analysis before use } \\
\text { - Confounding presence of immature RBCs in samples }\end{array}$ \\
\hline
\end{tabular}

based. The other three methods indirectly determine ploidy by measuring DNA content (flow cytometry), nuclear volume (Coulter counter analysis), or parameters of cell size that scale with ploidy (blood smear analysis). While all four methods have been used to assess ploidy level in sturgeons, their accuracy, utility, and appropriateness for use in commercial production or conservation aquaculture settings varies. Below we describe each method and summarize the attributes and limitations for each.

\section{Karyotyping}

Karyotyping is the counting and arranging of chromosomes in meiotic or mitotic cells, which is the most direct way to determine ploidy when the diploid number is known for a species. Cells from blood samples are spread on a glass slide, stained, and viewed under a microscope to count the number of chromosomes per cell. Chromosomes can also be arranged based on morphological similarity to identify homologous pairs. Karyotyping of gamete cells undergoing meiosis can determine how chromosomes are pairing (e.g. Van Eenennaam et al. 1998a, b). 
Karyotyping has been successfully performed for a number of sturgeon species, including American paddlefish (Polyodon spathula), Russian sturgeon (Acipenser gueldenstaedti), stellate sturgeon (A. stellatus), beluga (Huso huso), Siberian sturgeon, white sturgeon, Adriatic sturgeon (A. naccari), sterlet, shortnose sturgeon, Atlantic sturgeon, European sturgeon (A. sturio), and Sakhalin sturgeon (A. mikadoi) (Dingerkus and Howell 1976; Birstein and Vasiliev 1987; Fontana 1994; Van Eenennaam et al. 1998b; Fontana et al. 2008a, b; Zhou et al. 2013; Symonová et al. 2013; Havelka et al. 2016).

Karyotyping is a highly accurate means to determine ploidy of an individual (assuming the diploid karyotype is known) because the method counts actual chromosomes rather than relying on indirect measures. However, it is time consuming and requires significant technical expertise. Before sample collection, fish must be treated with a toxic chemical such as colchicine to arrest cellular division. Meiotic karyotyping has been limited to males because they have the required abundance of gametes during early stages of maturity (Table 3).

\section{Flow cytometry}

Flow cytometry determines ploidy by measuring the DNA content in cell nuclei relative to a known standard. This involves staining cellular DNA with a fluorescent dye such as propidium iodide (PI) or 4',6diamidino-2-phenylindole (DAPI) that will fluoresce when hit by a laser operating at a particular wavelength. Sample fluorescence is measured by a flow cytometer and can be compared to the fluorescence of a standard with known genome size. The following equation can be used to determine the sample genome size in picograms (pg):

\section{Sample DNA content $=$ Standard DNA content

$$
\times \frac{\text { fluorescence of sample }}{\text { fluorescence of standard }}
$$

Because erythrocytes are nucleated in fishes, blood provides an excellent source of cells for flow cytometry. Both blood and somatic tissue have been reported as cell sources for flow cytometry in sturgeon (Omoto et al. 2005; Schreier et al. 2013; Havelka et al. 2014).

Flow cytometry is highly accurate and considered the "gold standard" of indirect means to determine ploidy, requiring no validation. Initial studies of DNA content and ploidy of sturgeon were performed using flow cytometry (Birstein et al. 1993; Blacklidge and Bidwell 1993). Commercially available standards derived from species with known DNA content similar to sturgeons are available (e.g. rainbow trout), which improves analysis accuracy. Because the amount of blood required for flow cytometry is small $(\sim 25 \mu \mathrm{l}$; Schreier et al. 2013; Gille et al. 2015), most life stages can be non-lethally sampled for flow cytometry analysis. Many universities and diagnostic labs have flow cytometry instruments that can analyze blood or tissue samples.

However, flow cytometry may not be the best method of ploidy determination for hatcheries in remote locations, particularly when blood is used, due to the need to maintain samples under specific conditions prior to analysis. Because erythrocytes must settle out of whole blood samples before they can be used for flow cytometry, they must be transported to the lab with minimal disturbance, must be maintained at $\sim 4^{\circ} \mathrm{C}$, and, unless they are fixed, must be analyzed within $48 \mathrm{~h}$ of collection. Preparing blood or tissue samples for flow cytometry and operating a flow cytometer requires technical expertise. Furthermore, it may not always be cost-effective for production facilities to perform their own flow cytometry because necessary instrumentation is relatively expensive (e.g. a small bench-top flow cytometer, the Millipore Sigma Muse Cell Analyzer, costs $>\$ 16,000$ ). Additional attributes and limitations of flow cytometry to determine ploidy are presented in Table 3 .

\section{Coulter counter analysis}

Coulter counter analysis is based on the Coulter principle of electrical resistance in which disruption of an electrical field associated with electrolyte displacement is measured as a voltage pulse by a Coulter counter and translated into an estimate of a particle's size. More detailed information about the Coulter principle is provided by Beckman Coulter, the manufacturer of Coulter counters (http://www.beckman. com/particle/the-coulter-principle). Consistent with the significant correlation between genome size and erythrocyte size (Gregory 2001), erythrocytes and erythrocyte nuclei of spontaneous autopolyploid sturgeon are typically larger than those of diploid sturgeon. Therefore, Coulter counter analysis can be used to assign ploidy to a sample based on the size of 
its cells or cell nuclei. Recent comparisons of data generated from whole cells and nuclei revealed that cell nuclei consistently produced better quality data than whole cells in white sturgeon (Fiske et al. 2019). Validation of Coulter counter analysis with flow cytometry has shown $100 \%$ concordance between the methods. Coulter counter analysis has been reliably used to distinguish between diploid and spontaneous autopolyploid Atlantic sturgeon, and between diploid, spontaneous autopolyploid, and intermediate ploidy white sturgeon (Fiske et al. 2019; Schreier and Van Eenennaam 2016).

The most important positive attribute of the Coulter counter method is its high level of accuracy relative to flow cytometry $(100 \%)$. Coulter counter analysis requires very little blood (1-2 $\mu$ l whole blood), which allows screening earlier life stages of sturgeon than possible with flow cytometry. Compared to other methods, handling and transportation of samples for Coulter counter analysis is simplified because blood cells do not need to settle, and once stabilized in an electrolyte solution, refrigerated samples are suitable for analysis for six days or more with no reduction in data quality (Fiske et al. 2019). While this may still be logistically challenging for hatcheries or field sampling programs in remote locations, it allows time for batches of samples to be transported or shipped if the Coulter counter isn't on site. Preparation of samples for Coulter counter analysis and operation of a Coulter counter instrument is less technically demanding than required for flow cytometry, and production facilities can feasibly operate their own instruments. Because a blood sample can be prepared for Coulter counter analysis in several minutes, hundreds of samples can be screened in a single day. Solutions used in Coulter counter analysis are less toxic than flow cytometry reagents, and no standard is required.

However, a new Coulter counter instrument is more costly than a benchtop flow cytometer $(\sim \$ 42,000$ for a Beckman Coulter Multisizer 3 Coulter Counter), although used/refurbished units and older models ( $\mathrm{Z}$ series) may be available. In addition, care must be taken to standardize sample storage and analysis conditions to ensure data reproducibility. For example, temperature differences between samples can shift estimated modal nucleus sizes. Additional attributes and limitations of Coulter counter analysis are presented in Table 3.

\section{Blood smear analysis}

As in Coulter counter analysis, blood smear analysis is based on the principle that an increase in genome size causes a concomitant increase in nuclear and cell size. Blood smear analysis to determine ploidy of fishes focuses on nucleated erythrocytes, which have a relatively uniform size and shape when compared to leukocytes. To perform a blood smear analysis to determine ploidy, a film of blood is applied to a glass microscope slide, the slide is dried, and blood cells are fixed to it. Wright Giemsa or Feulgen staining can increase the visibility of erythrocytes or DNA for nuclear measurements. A microscope camera is used to capture images of mature erythrocytes, and software programs such as the freely available ImageJ (https:// imagej.nih.gov/ij/) can be used to measure various cell size parameters, including cell long axis length, cell width, and cell or nuclear surface area or volume (Small and Benfey 1987; Garcia-Abiado et al. 1999; Hardie and Hebert 2003).

Blood smear analysis has been used successfully to distinguish between diploids and triploids of several fish species, including some sturgeons (Wolters et al. 1982; Benfey et al. 1984; Garcia-Abiado et al. 1999; Bytyutskyy et al. 2014). However, a large study validating Coulter counter and blood smear analyses for ploidy determination in white sturgeon showed limited success. In one population of sturgeon, diploid and spontaneous autopolyploid individuals could be reliably distinguished with blood smears, but intermediate ploidy $(10 \mathrm{~N})$ progeny could not (Fiske et al. 2019). In another population, variability in erythrocyte long axis lengths within diploids and spontaneous autopolyploids was too great to reliably distinguish between them (Fiske et al. 2019).

Blood smear analysis requires the least amount of equipment and expertise of the four ploidy detection methods described here. Only a small amount $(2-3 \mu \mathrm{l})$ of blood is required, so earlier life stages can be screened compared to flow cytometry. Blood smears are also logistically simpler, allowing for large numbers of samples to be collected in the field during assessment of wild populations. Like Coulter counter analysis, no standard is required for this method. Raw data can be compared between experiments because environmental conditions do not change cell size measurements after cells are fixed on the slide. 
However, to date, the blood smear method has shown the lowest accuracy of the four available ploidy determination methods reviewed here and requires validation with either flow cytometry or Coulter counter analysis before it can be used. Due to the prevalence of immature erythrocytes in fish blood (10-12\%; Witeska 2013), care must be taken to measure only mature erythrocytes in these fish to avoid overestimating mean long-axis length. Persample preparation and analysis time $(15-20 \mathrm{~min})$ is longer than that needed for Coulter counter analysis. Additional attributes and limitations of blood smear analysis are presented in Table 3.

Recommendations for management to detect and reduce the incidence of spontaneous autopolyploidy in sturgeon

Consistent with highly accurate detection methods and recent insights into the potential causes of spontaneous autopolyploidy described above, we recommend a series of best hatchery practices to help sturgeon aquaculturists minimize the incidence and risk of spontaneous autopolyploidy. Although some of these practices are taxon or program (commercial vs. conservation) specific, some can be applied to any fish culture program looking to minimize the risk of spontaneous autopolyploidy.

\section{Best hatchery practices}

Every hatchery program, whether for conservation and recovery, harvest in recreational fisheries, or commercial production, is accompanied by a set of benefits and risks. Optimal management objectives and policy decisions are typically designed to maximize benefits and minimize risk in the face of uncertainty (Walters 1986). In order to ensure due diligence to minimize the incidence and risks of spontaneous autopolyploidy, we recommend the following series of best practices.

Six general best practices are described below in detail, accompanied by 14 specific best practices (Table 4) to reduce the incidence and risk of spontaneous autopolyploidy in commercial and conservation sturgeon aquaculture programs.
1. Detailed data collection: Collect detailed and standardized data for all females that are spawned in culture, including date of capture and river temperature at capture for conservation programs, initial polarization index (PI), a ratio of the distance of the germinal vesicle from the animal pole to the oocyte diameter (animal-vegetal axis) (Chapman and Van Eenennaam 2007), ploidy, holding temperature until injection, final PI before injecting, days after final PI and 1st injection, temperature during injections/ovulation, latency after 2nd injection to first observed eggs, rate of egg release (estimate eggs released each hour until eggs are collected), time after first oviposition and ovulated egg collection, time after egg collection and fertilization (in vitro ageing), and egg silting method/description and duration. Tagging broodstock with PIT tags or visible external tags can facilitate individual identification for data collection. For programs that non-lethally obtain eggs via manual stripping, record the time between stripping events if stripped more than once. PI values should be determined on a minimum of 10 properly sectioned eggs. Estimate fertility and hatch rate to identify low quality eggs more likely to contain spontaneous autopolyploids. Randomly sample 100-200 eggs at the 4-cell stage $(\sim 6 \mathrm{~h}$ after fertilization) and at $>60 \mathrm{~h}$ post-fertilization (late-neurulation, stage 22; Dettlaff et al. 1993) when incubated at $15-15.5^{\circ} \mathrm{C}$ to estimate fertility and hatch, respectively. The post-neurulation sample should occur after flow rates are increased to thoroughly mix the eggs, as dead eggs tend to accumulate in the top half of the jar under the initial low flows. A large decline between fertility rate and neurulation rate usually indicates poor egg quality, which can lead to a higher incidence of spontaneous autopolyploid progeny. Data on growth and survival following hatch will also be important to identifying poor performance that could be associated with spontaneous autopolyploidy.

2. Hold pre-spawned male and female broodstock in same tank: Several studies have suggested that chemocommunication between male and female sturgeon occurs at spawning and impacts final maturation (Kynard and Horgan 2002; Bayunova et al. 2011; Kasumyan and Mamedov 2011; Bayunova 2016). Females held separately from 
Table 4 Best practices for managing spontaneous autopolyploidy in Acipenseriformes hatchery programs that spawn broodstock in captivity

\begin{tabular}{|c|c|c|}
\hline Timeframe & Life stage & Best practices \\
\hline Annual & $\begin{array}{l}\text { Pre-spawning } \\
\text { broodstock }\end{array}$ & $\begin{array}{l}\text { 1. Screen all potential broodstock for ploidy level prior to spawning (annual for } \\
\text { conservation hatcheries; for farms, after their initial screening of all tagged } \\
\text { broodstock, check new additions into the broodstock population) } \\
\text { 2. Spawn only diploid fish } \\
\text { 3. Cull spontaneous autopolyploid fish from broodstock }\end{array}$ \\
\hline Annual & Broodstock/eggs & $\begin{array}{l}\text { 4. Inject female broodstock at a species' specific optimal PI (e.g. } 0.06-0.10 \text { for white } \\
\text { sturgeon) and within } 10-14 \text { days of the last PI check } \\
\text { 5. Maintain optimal water quality parameters during final maturation and spawning } \\
\text { induction } \\
\text { 6. Collect eggs within } 1-4 \mathrm{~h} \text { after oviposition (farms) and within } 2-5 \mathrm{~h} \text { if manually } \\
\text { stripping (conservation aquaculture) }\end{array}$ \\
\hline Annual & Eggs/Embryos & $\begin{array}{l}\text { 7. Minimize agitation (slow and gentle) during de-adhesion } \\
\text { 8. Maintain optimal water quality parameters during egg collection, de-adhesion, and } \\
\text { incubation }\end{array}$ \\
\hline $\begin{array}{l}\text { Annual (for } \\
\text { conservation } \\
\text { aquaculture) }\end{array}$ & Age-0 & $\begin{array}{l}\text { 9. Initially screen each maternal family to determine ploidy ( } n=50-100 \text { fish, } \\
\text { depending on family size) } \\
\text { 10. Re-test families with spontaneous autopolyploid individuals using large samples } \\
\text { sizes ( } n=90-150 \text { fish, depending on family size) to characterize proportions of } \\
\text { each ploidy } \\
\text { 11. Repatriation programs whose progeny may originate from numerous maternal } \\
\text { families should test all individuals before release }\end{array}$ \\
\hline $\begin{array}{l}\text { Annual (for } \\
\text { conservation } \\
\text { aquaculture) }\end{array}$ & $\begin{array}{l}\text { Pre-release } \\
\text { juveniles }\end{array}$ & $\begin{array}{l}\text { 12. Repeat } 9 \text { and } 10 \text { (above) for any previously produced, untested families retained } \\
\text { in the hatchery }\end{array}$ \\
\hline $\begin{array}{l}\text { Annual (for } \\
\text { conservation } \\
\text { aquaculture) }\end{array}$ & $\begin{array}{l}\text { Post-release } \\
\text { juveniles }\end{array}$ & $\begin{array}{l}\text { 13. Perform ploidy screening on hatchery origin juveniles when recaptured in the } \\
\text { wild }\end{array}$ \\
\hline Longer-term & $\begin{array}{l}\text { Broodstock, } \\
\text { Eggs/Embryos }\end{array}$ & $\begin{array}{l}\text { 14. Support and participate in critical uncertainty research/experiments to minimize } \\
\text { incidence and risk of spontaneous autopolyploidy }\end{array}$ \\
\hline
\end{tabular}

males will not display spawning behaviors and may release eggs over a more protracted period of time, resulting in in vivo oocyte ageing (Dettlaff et al. 1993). If wild broodstock are captured well in advance of spawning, conservation hatcheries should consider holding males and females in the same tank to facilitate ovulation. This recommendation is based on our current understanding of sturgeon reproductive biology, but further research is needed to document the effects of this practice on spontaneous autopolyploidy.

3. Timing of hormone injection: The optimal PI, timing for hormone injection, and spawning/ embryo incubation temperature can vary between sturgeon species, so aquaculture programs for different species may need to establish their own basis for the following parameters. For white sturgeon programs, females should be injected at a PI of 0.06-0.10 and within 10-14 days of the last PI check for females held at $15{ }^{\circ} \mathrm{C}$. The process of final maturation is temperature dependent, so the time to inject will be shorter in warmer water and can be a bit longer in colder water. Injection of females with a very low PI $(<0.05)$ may increase the incidence of overripe eggs, especially for captive stocks or wild-caught females held for extended periods. However, a freshly wild-caught female with a very low PI value may be perfect for spawning as she has been exposed to natural 
environmental cues in the river and is close to ovulation.

4. Handle eggs very gently during de-adhesion: If performing de-adhesion manually, use a feather when fertilizing smaller batches of eggs or a hand if needed, for a large quantity of eggs. Slowly and carefully fold eggs and silt together off the bottom of the bowl for approximately $60 \mathrm{~min}$. Although it may be necessary to stir continuously for the first few minutes, depending on the degree of egg stickiness, continuous stirring for the full deadhesion period may not be necessary. The degree of egg stickiness and how fast the jelly coat forms is highly variable among females and temperature dependent, so the exact de-adhesion process will vary. For programs that use mechanical deadhesion in a conical vessel, ensure flow rates of water or air are low enough that the eggs roll very slowly. When possible, ensure the source of the flow is diffused at the bottom of the vessel so that eggs gently roll in an upwelling fashion rather than a random, jetting action that may be too vigorous.

5. Screen all male and female broodstock and each maternal family produced in the hatchery for spontaneous autopolyploids. If present, conduct additional screening: Rigorous testing is required at several life stages to ensure risks related to spontaneous autopolyploidy are characterized. Both commercial and conservation programs should identify ploidy levels of all broodstock before spawning. Never spawn spontaneous autopolyploid broodstock to avoid creating intermediate ploidy progeny. For conservation programs, randomly sample a minimum of 50 individuals from each maternal family for ploidy screening using methods of high accuracy (Table 3). For large families (> 1000 individuals), the number of individuals screened should be increased to 100. If maternal families are found to contain spontaneous autopolyploids, managers may wish to know what proportion of the progeny are triploid to determine how to handle the situation. We recommend randomly sampling blood from 90 to 150 additional individuals for small to large families, respectively, to better characterize the proportion of spontaneous autopolyploid progeny in a maternal family. We suggest selecting samples from the distribution of sizes (length or weight) present within the family at the time of sampling in case diploids and spontaneous autopolyploids differ in growth performance. Once the proportion of spontaneous autopolyploid progeny per family has been determined, managers can decide whether to continue rearing the family for production or release, to cull spontaneous autopolyploids, or cull an entire maternal family. We cannot recommend a single spontaneous autopolyploidy threshold beyond which a family should not be reared or released. This decision must be made by individual conservation programs, considering program goals and objectives, risk factors, risk tolerance, funding, equipment availability, and staffing.

6. Cull problematic broodstock: Spontaneous autopolyploid broodstock, male or female, will always produce progeny of abnormal ploidy and are of no value to commercial or conservation aquaculture programs wishing to produce normal fish. However, the decision to cull individuals may be easier for commercial programs with captive broodstock compared to conservation programs where broodstock are sourced from imperiled wild populations. For the latter, decisions will be made by individual programs and agencies. Lastly, culling should also be considered for female broodstock that consistently produce high numbers of spontaneous autopolyploid progeny. The only programs to which this recommendation would not apply are commercial caviar farms wishing to preferentially rear spontaneous autopolyploids or triploidize spontaneous autopolyploids to obtain larger eggs,

Special considerations for conservation aquaculture programs

For sturgeon conservation aquaculture programs, issues related to spontaneous autopolyploidy arose relatively recently and most programs were initiated before the risks were fully identified. Production and release of progeny occurred for many years before ploidy screening was implemented. As highlighted in this review, most white sturgeon programs detected spontaneous autopolyploids when they started screening and therefore assume that triploid progeny have been released into the wild annually since the program's inception. For Group B sturgeon recovery 
programs looking to restore wild recruitment, the risk of spontaneous autopolyploids reproducing with wild adults and producing progeny of intermediate ploidy with reduced reproductive capacity could jeopardize the program's effectiveness and ultimately recovery goals. This risk is further compounded for programs that have transitioned to rearing wild-origin young of year for repatriation (e.g. Thorstensen et al. 2019). Hatchery-origin spontaneous autopolyploids from early releases may soon reach puberty and spawn with wild fish, producing intermediate ploidy progeny in the wild. While intermediate ploidy progeny would be detected in hatchery screening programs, spontaneous autopolyploid hatchery-origin fish directly reduce the reproductive success of wild spawning fish. Accordingly, while within-hatchery screening is critical for conservation programs, screening of hatchery-origin fish at large in the wild is also important to understand the potential risks spontaneous autopolyploidy may pose for recovery efforts.

Discussions around management implications have been challenged by a lack of information related to the risks of spontaneous autopolyploidy and the incidence both within the hatchery and in the wild population. Most conservation programs have adopted a cautionary approach where screening is used to detect spontaneous autopolyploids (broodstock, captive progeny, or wild-origin progeny for repatriation) and those individuals are not released (e.g. Kootenai and Upper Columbia white sturgeon recovery programs). Information on the number of hatchery-origin spontaneous autopolyploids at large in the wild is being collected in many populations to further inform management alternatives. For example, ploidy screening was implemented in the lower Columbia River in Canada from 2014 to 2018 using both blood smears and Coulter counter methods which identified hatchery-origin spontaneous autopolyploids within the majority of year classes at large. However, mitigative actions for spontaneous autopolyploids at large in the wild are limited because testing does not occur real time, while fish are in hand, so selective removals would be logistically challenging. Larger screening programs are required to understand the proportion of spontaneous autopolyploids at large in the wild so management actions can be developed.

\section{Conclusions}

Relative to other fishes, spontaneous autopolyploidy occurs frequently in sturgeon, particularly in culture, and can pose a risk to commercial production goals and conservation programs. Spontaneous autopolyploids and especially their intermediate ploidy progeny exhibit physiological and reproductive differences from normal individuals that can impact farm productivity or wild population recovery. Recent investigations into the causes of spontaneous autopolyploidy and the best methods of detection have allowed us to compile a list of short-term (annual) and longer term (multi-year) Best Hatchery Practices (Table 4) that when followed, will minimize this risk. Although spontaneous autopolyploidy may never be completely eliminated from conventional hatchery programs, actions taken to maximize egg quality coupled with vigilant screening of broodstock and progeny can significantly reduce its incidence and risk. Importantly, for conservation programs that may have released spontaneous autopolyploids into wild populations, screening in the wild in addition to within hatchery practices is critical to ensure recovery goals are not jeopardized.

Acknowledgements We would like to thank the Bonneville Power Administration and the Columbia River Inter-Tribal Fisheries Commission (BPA-CRITFC Project \#2007-155-00) for funding to support the drafting of this manuscript. We also thank Ray Beamesderfer (Fish Science Solutions, Portland, OR) for supporting publication efforts and for his long-term contributions to sturgeon management, aquaculture, and conservation. We'd like to acknowledge the Kootenai Tribe of Idaho and the Western Regional Aquaculture Center (WRAC) for their initial investments in quantifying and determining the causes of spontaneous autopolyploidy in white sturgeon. Thank you to Mary Badger for help with synthesizing literature on the incidence of spontaneous autopolyploidy in wild populations. Finally, we thank Aviva Fiske for sharing the photos for Fig. 1.This manuscript is dedicated to the memory of Dr. Paul Anders, a great colleague and friend who made significant contributions to sturgeon recovery and fisheries science in the Pacific Northwest.

Funding Bonneville Power Administration and the Columbia River Inter-Tribal Fisheries Commission (BPA-CRITFC Project \# 2007-155-00).

\section{Compliance with ethical standards}

Conflict of interest The author declare that they have no conflict of interest. 
Open Access This article is licensed under a Creative Commons Attribution 4.0 International License, which permits use, sharing, adaptation, distribution and reproduction in any medium or format, as long as you give appropriate credit to the original author(s) and the source, provide a link to the Creative Commons licence, and indicate if changes were made. The images or other third party material in this article are included in the article's Creative Commons licence, unless indicated otherwise in a credit line to the material. If material is not included in the article's Creative Commons licence and your intended use is not permitted by statutory regulation or exceeds the permitted use, you will need to obtain permission directly from the copyright holder. To view a copy of this licence, visit http://creativecommons.org/licenses/by/4.0/.

\section{References}

Abbas K, Li MY, Wang WM, Zhou XY (2009) First record of the natural occurrence of hexaploid loach, Misgurnus anguillicaudatus in Hubei Province, China. J Fish Biol 75:435-441. https://doi.org/10.1111/j.1095-8649.2009. 02320.x

Abdel-Hameed MF, Neat HJ (1972) A study on erythrocyte cell volume and number in normal adult and triploid intersex chickens. Poult Sci 51:1376-1382. https://doi.org/10.3382/ ps.0511376

Aegerter S, Jalabert B (2004) Effects of post-ovulatory oocyte ageing and temperature on egg quality and on the occurrence of triploid fry in rainbow trout, Oncorhynchus mykiss. Aquaculture 231:59-71. https://doi.org/10.1016/j. aquaculture.2003.08.019

Al Sabti K, Kurelec B, Fijian N (1983) Spontaneous triploidy and tetraploidy in the common carp (Cyprinus carpio L.). Vet Arh 53:217-223

Allen SK, Stanley JG (1983) Ploidy of hybrid grass carp X bighead carp determined by flow cytometry. Trans Am Fish Soc 112:431-435. https://doi.org/10.1577/15488659(1983)112\%3c431:pohgcx\%3e2.0.co;2

Atkins ME, Benfey TJ (2008) Effect of acclimation temperature on routine metabolic rate in triploid salmonids. Comp Biochem Physiol-A Mol Integr Physiol 149:157-161. https://doi.org/10.1016/j.cbpa.2007.11.004

Aussanasuwannakul A, Kenney PB, Weber GM et al (2011) Effect of sexual maturation on growth, fillet composition, and texture of female rainbow trout (Oncorhynchus mykiss) on a high nutritional plane. Aquaculture 317:79-88. https:// doi.org/10.1016/j.aquaculture.2011.04.015

Ballarin L, Dall' Oro M, Bertotto D et al (2004) Haematological parameters in Umbrina cirrosa (Teleostei, Sciaenidae): A comparison between diploid and triploid specimens. Comp Biochem Physiol A Mol Integr Physiol 138:45-51. https:// doi.org/10.1016/j.cbpb.2004.02.019

Bayunova L, Semenkova T, Canario AVM et al (2011) Free and conjugated androgen and progestin levels in the serum of stellate sturgeon (Acipenser stellatus Pallas) males treated with female coelomic fluid. J Appl Ichthyol 27:655-659. https://doi.org/10.1111/j.1439-0426.2011.01686.x

Bayunova LV (2016) The effect of four C21-steroids on oocyte maturation in Siberian sturgeon (Acipenser baeri Brandt).
J Evol Biochem Physiol 52:431-439. https://doi.org/10. 1134/S123456781606001X

Benfey TJ (1989) A bibliography of triploid fish, 1943-1988. West Vancouver, British Columbia

Benfey TJ, Solar II, De Jong G, Donaldson EM (1986) Flowcytometric confirmation of aneuploidy in sperm from triploid rainbow trout. Trans Am Fish Soc 115:838-840. https://doi.org/10.1577/1548-8659(1986)115\%3c838: fcoais\%3e2.0.co;2

Benfey TJ, Sutterlin AM, Thompson RJ (1984) Use of erythrocyte measurements to identify triploid salmonids. Can J Fish Aquat Sci 41:980-984

Beyea MM, Benfey TJ, Kieffer JD (2005) Hematology and stress physiology of juvenile diploid and triploid shortnose sturgeon (Acipenser brevirostrum). Fish Physiol Biochem 31:303-313. https://doi.org/10.1007/s10695-005-1552-y

Birstein VJ, Poletaev AI, Goncharov BF (1993) DNA content in Eurasian sturgeon species determined by flow cytometry. Cytometry 14:377-383. https://doi.org/10.1002/cyto. 990140406

Birstein VJ, Vasiliev VP (1987) Tetraploid-octoploid relationships and karyological evolution in the order Acipenseriformes (Pisces) Karyotypes, nucleoli, and nucleolusorganizer regions in four acipenserid species. Genetica $72: 3-12$

Blacklidge KH, Bidwell CA (1993) Three ploidy levels indicated by genome quantification in Acipenseriformes of North America. J Hered 84:427-430

Borin LA, Martins-Santos IC, Oliveira C (2002) A natural triploid in Trichomycterus davisi (Siluriformes, Trichomycteridae): mitotic and meiotic characterization by chromosome banding and synaptonemal complex analyses. Genetica 115:253-258

Bowden AJ, Andrewartha SJ, Elliott NG et al (2018) Negligible differences in metabolism and thermal tolerance between diploid and triploid Atlantic salmon (Salmo salar). J Exp Biol. https://doi.org/10.1242/jeb.166975

Bronzi P, Chebanov M, Michaels JT et al (2019) Sturgeon meat and caviar production: global update 2017. J Appl Ichthyol 35:257-266. https://doi.org/10.1111/jai.13870

Bytyutskyy D, Kholodnyy V, Flajshans M (2014) 3-D structure, volume, and DNA content of erythrocyte nuclei of polyploid fish. Cell Biol Int 38:708-715. https://doi.org/10. 1002/cbin. 10247

Bytyutskyy D, Srp J, Flajšhans M (2012) Use of Feulgen image analysis densitometry to study the effect of genome size on nuclear size in polyploid sturgeons. J Appl Ichthyol 28:704-708. https://doi.org/10.1111/j.1439-0426.2012. 02021.x

Cal RM, Vidal S, Gómez C et al (2006) Growth and gonadal development in diploid and triploid turbot (Scophthalmus maximus). Aquaculture 251:99-108. https://doi.org/10. 1016/j.aquaculture.2005.05.010

Carter CG, Mccarthy ID, Houlihan DF et al (1994) Food consumption, feeding behaviour, and growth of triploid and diploid Atlantic salmon, Salmo salar L., parr. Can J Zool 72:609-617

Centofante L, Bertollo LAC, Moreira-Filho O (2001) Comparative cytogenetics among sympatric species of Characidium (Pisces, Characiformes). Diversity analysis with the description of a ZW sex chromosome system and natural 
triploidy. Caryologia 54:253-260. https://doi.org/10.1080/ 00087114.2001 .10589233

Chapman FA, Van Eenennaam JP (2007) Sturgeon aquaculture-specialized techniques determining the stage of sexual maturity in female sturgeon for artificial spawning: the egg polarization index or PI (FA 153). University of Florida IFAS Extension, Gainesville

Cherfas N, Gomelsky B, Ben-Dom N, Hulata G (1995) Evidence for the heritable nature of spontaneous diploidization in common carp, Cyprinus carpio L., eggs. Aquac Res 26:289-292

Chernenko YV (1968) Karyotypes of dwarf (residual) and anadromous forms of sockeye salmon [Oncorhynchus nerka (Walb.)] from Lake Dalnee (Kamchatka). Probl Ichthyol 8:668-677

Cherr GN, Clark WH (1985) Gamete interaction in the white sturgeon Acipenser transmontanus: a morphological and physiological review. Environ Biol Fishes 14:11-22. https://doi.org/10.1007/BF00001572

Chiasson M, a., Pelletier CS, Benfey TJ, (2009) Triploidy and full-sib family effects on survival and growth in juvenile Arctic charr (Salvelinus alpinus). Aquaculture 289:244-252. https://doi.org/10.1016/j.aquaculture.2009. 01.010

Cristina A, Malacrida CP, Dias AL, Giuliano-Caetano L (2003) Natural triploidy in Astyanax aff. scabripinnis (Pisces, Characidae) of the Tibagi river bay-PR. Cytologia (Tokyo) 68:267-270. https://doi.org/10.1508/cytologia.68.267

Cuellar O, Uyeno T (1972) Triploidy in rainbow trout. Cytogenetics 11:508-515

De Almeida Toledo LF, Foresti F, De Almeida Toledo Filho S (1985) Spontaneous triploidy and NOR activity in Eigenmannia sp. (Pisces, Sternopygidae) from the Amazon basin. Genetica 66:85-88. https://doi.org/10.1007/ BF00139713

Dettlaff T, Ginsburg A, Schmalhausen O (1993) Sturgeon fishes: developmental biology and aquaculture. Springer, New York

Devlin RH, Sakhrani D, Biagi CA, Eom KW (2010) Occurrence of incomplete paternal-chromosome retention in $\mathrm{GH}$ transgenic coho salmon being assessed for reproductive containment by pressure-shock-induced triploidy. Aquaculture 304:66-78. https://doi.org/10.1016/j.aquaculture. 2010.03.023

Dingerkus G, Howell WM (1976) Karyotypic analysis and evidence of tetraploidy in the North American Paddlefish, Polyodon spathula. Science (80) 194:842-844

Dorafshan S, Kalbassi MR, Pourkazemi M et al (2008) Effects of triploidy on the Caspian salmon Salmo trutta caspius haematology. Fish Physiol Biochem 34:195-200. https:// doi.org/10.1007/s10695-007-9176-Z

Drauch Schreier A, Gille D, Mahardja B, May B (2011) Neutral markers confirm the octoploid origin and reveal spontaneous autopolyploidy in white sturgeon, Acipenser transmontanus. J Appl Ichthyol 27:24-33. https://doi.org/10. 1111/j.1439-0426.2011.01873.x

Drozd B, Flajšhans M, Ráb P (2010) Sympatric occurrence of triploid, aneuploid and tetraploid weatherfish Misgurnus fossilis (Cypriniformes, Cobitidae). J Fish Biol 77:2163-2170. https://doi.org/10.1111/j.1095-8649.2010. 02794.x
Du K, Stöck M, Kneitz S et al (2020) The sterlet sturgeon genome sequence and mechanisms of segmental rediploidization. Nat Ecol Evol. https://doi.org/10.1038/ s41559-020-1166-x.10.1038/s41559-020-1166-x

Fauaz G, Vicente VE, Moreira-Filho O (1994) Natural triploidy and $\mathrm{B}$ chromosomes in the fish genus Astyanax (Characidae). Brazillian J Genet 17:157-163

Feindel NJ, Benfey TJ, Trippel EA (2010) Competitive spawning success and fertility of triploid male Atlantic cod Gadus morhua. Aquac Environ Interact 1:47-55. https:// doi.org/10.3354/aei00006

Fernandes-Matioli FMC, Almeida-Toledo LF, Toledo-Filho SA (1998) Natural triploidy in the Neotropical species Gymnotus carapo (Pisces: Gymnotiformes). Caryologia 51:319-322. https://doi.org/10.1080/00087114.1998. 10797423

Fiske JA, Van Eenennaam JP, Todgham AE et al (2019) A comparison of methods for determining ploidy in white sturgeon (Acipenser transmontanus). Aquaculture 507:435-442. https://doi.org/10.1016/j.aquaculture.2019. 03.009

Flajšhans M, Kohlmann K, Ráb P (2007) Autotriploid tench Tinca tinca (L.) larvae obtained by fertilization of eggs previously subjected to postovulatory ageing in vitro and in vivo. J Fish Biol 71:868-876. https://doi.org/10.1111/j. 1095-8649.2007.01557.x

Flajshans M, Kvasnicka P, Ráb P (1993) Genetic studies in tench (Tinca tinca L.): high incidence of spontaneous triploidy. Aquaculture 110:243-248

Flynn SR, Matsuoka M, Reith M et al (2006) Gynogenesis and sex determination in shortnose sturgeon, Acipenser brevirostrum Lesuere. Aquaculture 253:721-727. https://doi. org/10.1016/j.aquaculture.2005.09.016

Fontana F (1994) Chromosomal nucleolar organizer regions in four sturgeon species as markers of karyotype evolution in Acipenseriformes (Pisces). Genome 37:888-892

Fontana F, Congiu L, Mudrak VA et al (2008a) Evidence of hexaploid karyotype in shortnose sturgeon. Genome 51:113-119. https://doi.org/10.1139/G07-112

Fontana F, Lanfredi M, Kirschbaum F et al (2008b) Comparison of karyotypes of Acipenser oxyrinchus and A. sturio by chromosome banding and fluorescent in situ hybridization. Genetica 132:281-286. https://doi.org/10.1007/s10709007-9171-4

Fopp-Bayat D (2010) Meiotic gynogenesis revealed not homogametic female sex determination system in Siberian sturgeon (Acipenser baeri Brandt). Aquaculture 305:174-177. https://doi.org/10.1016/j.aquaculture.2010. 04.011

Fraser TWK, Hansen T, Skjæraasen JE et al (2013) The effect of triploidy on the culture performance, deformity prevalence, and heart morphology in Atlantic salmon. Aquaculture 416-417:255-264. https://doi.org/10.1016/j. aquaculture.2013.09.034

Gao Z, Wang W, Abbas K et al (2007) Haematological characterization of loach Misgurnus anguillicaudatus: comparison among diploid, triploid and tetraploid specimens. Comp Biochem Physiol A Mol Integr Physiol 147:1001-1008. https://doi.org/10.1016/j.cbpa.2007.03. 006 
Garcia-Abiado MAR, Dabrowski K, Christensen JE et al (1999) Use of erythrocyte measurements to identify triploid saugeyes. N Am J Aquac 61:319-325. https://doi.org/10.1139/ f84- 112

Garcia C, Moreira-Filho O, Bertollo LAC, Centofante L (2003) B Chromosomes and natural triploidy in Rhamdia sp. (Pisces, Siluriformes, Heptapteridae). Cytologia (Tokyo) 68:403-411. https://doi.org/10.1508/cytologia.68.403

Gilkey JC (1981) Mechanisms of fertilization in fishes. Integr Comp Biol 21:359-375. https://doi.org/10.1093/icb/21.2. 359

Gille DA, Famula TR, May BP, Schreier AD (2015) Evidence for a maternal origin of spontaneous autopolyploidy in cultured white sturgeon (Acipenser transmontanus). Aquaculture 435:467-474. https://doi.org/10.1016/j. aquaculture.2014.10.002

Ginsburg AS (1961) The block to polyspermy in sturgeon and trout with special reference to the role of cortical granules (alveoli). J Embryol Exp Morphol 9:173-190

Glover KA, Madhun AS, Dahle G et al (2015) The frequency of spontaneous triploidy in farmed Atlantic salmon produced in Norway during the period 2007-2014. BMC Genet 16:37. https://doi.org/10.1186/s12863-015-0193-0

Gold JR (1986) Spontaneous triploidy in a natural population of the fathead minnow, Pimephales promelas (Pisces: Cyprinidae). Southwest Nat 31:527-529

Gold JR, Avise JC (1976) Spontaneous triploidy in the california roach: Hesperoleucus symmetricus (pisces: Cyprinidae). Cytogenet Genome Res 17:144-149. https://doi.org/10. 1159/000130706

Gomelsky B, Schneider KJ, Anil A, Delomas TA (2015) Gonad development in triploid ornamental koi carp and results of crossing triploid females with diploid males. N Am J Aquac 77:96-101. https://doi.org/10.1080/15222055. 2014.963766

Grammeltvedt A-F (1974) A method of obtaining chromosome preparations from rainbow trout (Salmo gairdneri) by leucocyte culture. Nor J Zool 22:129-134

Gregory TR (2001) The bigger the C-value, the larger the cell: genome size and red blood cell size in vertebrates. Blood Cells, Mol Dis 27:830-843. https://doi.org/10.1006/bcmd. 2001.0457

Hansen TJ, Olsen RE, Stien L et al (2015) Effect of water oxygen level on performance of diploid and triploid Atlantic salmon post-smolts reared at high temperature. Aquaculture 435:354-360. https://doi.org/10.1016/j. aquaculture.2014.10.017

Hardie DC, Hebert PDN (2003) The nucleotypic effects of cellular DNA content in cartilaginous and ray-finned fishes. Genome 46:683-706. https://doi.org/10.1139/G03040

Havelka M, Bytyutskyy D, Symonová R et al (2016) The second highest chromosome count among vertebrates is observed in cultured sturgeon and is associated with genome plasticity. Genet Sel Evol 48:12. https://doi.org/10.1186/ s12711-016-0194-0

Havelka M, Hulák M, Ráb P et al (2014) Fertility of a spontaneous hexaploid male Siberian sturgeon, Acipenser baerii. BMC Genet 15:5. https://doi.org/10.1186/1471-2156-15-5

Havelka M, Hulák M, Rodina M, Flajšhans M (2013) First evidence of autotriploidization in sterlet (Acipenser ruthenus). J Appl Genet 54:201-207. https://doi.org/10. 1007/s13353-013-0143-3

Hildebrand LR, Schreier AD, Lepla K et al (2016) Status of White Sturgeon (Acipenser transmontanus Richardson, 1863) throughout the species range, threats to survival, and prognosis for the future. J Appl Ichthyol 32:261-312. https://doi.org/10.1111/jai.13243

Iegorova V, Havelka M, Psenicka M, Saito T (2018a) First evidence of viable progeny from three interspecific parents in sturgeon. Fish Physiol Biochem 44:1541-1550. https:// doi.org/10.1007/s10695-018-0553-6

Iegorova V, Psenicka M, Lebeda I et al (2018b) Polyspermy produces viable haploid/diploid mosaics in sturgeon. Biol Reprod 99:695-705. https://doi.org/10.1093/biolre/ioy092

Jaffe LA, Gould M (1985) Polyspermy-preventing mechanisms. In: Metz CB, Monroy A (eds) Biology of fertilization, Volume 3: the fertilization response of the egg. Academic Press Inc., Orlando, pp 223-224

Janhunen M, Vehviläinen H, Koskela J et al (2019) Added value from an added chromosome: potential of producing large fillet fish from autumn to spring with triploid rainbow trout, Oncorhynchus mykiss. Aquac Res 50:818-825. https://doi. org/10.1111/are.13952

Johnson MA, Noakes DLG, Friesen TA et al (2019) Growth, survivorship, and juvenile physiology of triploid steelhead (Oncorhynchus mykiss). Fish Res 220:105350. https://doi. org/10.1016/j.fishres.2019.105350

Johnson RM, Shrimpton JM, Heath JW, Heath DD (2004) Family, induction methodology and interaction effects on the performance of diploid and triploid chinook salmon (Oncorhynchus tshawytscha). Aquaculture 234:123-142. https://doi.org/10.1016/j.aquaculture.2004.01.024

Kantek DLZ, Noleto RB, Fenocchio AS, Cestari MM (2007) Cytotaxonomy, heterochromatic polymorphism and natural triploidy of a species of Astyanax (Pisces, Characidae) endemic to the Iguaçu river basin. Brazilian Arch Biol Technol 50:67-74. https://doi.org/10.1590/S151689132007000100008

Kasumyan AO, Mamedov CA (2011) Behavioral response of mature males of Acipenseridae to female sex pheromone. J Ichthyol 51:457-465. https://doi.org/10.1134/ S0032945211040072

Kendall C, Valentino S, Bodine AB, Luer CA (1994) Triploidy in a nurse shark, Ginglymostoma cirratum. Copeia 3:825-827

Kim DS, Nam YK, Noh JK et al (2005) Karyotype of North American shortnose sturgeon Acipenser brevirostrum with the highest chromosome number in the Acipenseriformes. Ichthyol Res 52:94-97. https://doi.org/10.1007/s10228004-0257-z

King TL, Henderson AP, Kynard BE et al (2014) A nuclear DNA perspective on delineating evolutionarily significant lineages in polyploids: the case of the endangered shortnose sturgeon (Acipenser brevirostrum). PLoS ONE. https://doi.org/10.1371/journal.pone.0102784

Kynard B, Horgan M (2002) Attraction of prespawning male shortnose sturgeon Acipenser brevirostrum to the odor of prespawning females.pdf. J Ichthyol 42:205-209

Lahnsteiner F, Lahnsteiner E, Kletzl M (2019) Differences in metabolism of triploid and diploid Salmo trutta f. lacustris under acclimation conditions and after exposure to stress 
situations. Aquac Res 2444-2459. https://doi.org/10.1111/ are. 14198

Leal MJ, Clark BE, Van Eenennaam JP et al (2018) The effects of warm temperature acclimation on constitutive stress, immunity, and metabolism in white sturgeon (Acipenser transmontanus) of different ploidies. Comp Biochem Physiol-Part A Mol Integr Physiol 224:23-34. https://doi. org/10.1016/j.cbpa.2018.05.021

Leal MJ, Van Eenennaam JP, Schreier AD, Todgham AE (2019) Triploidy in white sturgeon (Acipenser transmontanus): Effects of acute stress and warm acclimation on physiological performance. Comp Biochem Physiol-Part A Mol Integr Physiol 229:10-17. https://doi.org/10.1016/j.cbpa. 2018.11.006

Leal MJ, Van Eenennaam JP, Schreier AD, Todgham AE (2020) Diploid and triploid white sturgeon (Acipenser transmontanus ) differ in magnitude but not kinetics of physiological responses to exhaustive exercise at ambient and elevated temperatures. Can J Fish Aquat Sci 77:666-673. https:// doi.org/10.1139/cjfas-2019-0289

Lincoln RF (1981a) Sexual maturation in female triploid plaice, Pleuronectes platessa, and plaice $\times$ flounder, Platichthys flesus, hybrids. J Fish Biol 19:499-508. https://doi.org/10. 1111/j.1095-8649.1981.tb03818.x

Lincoln RF (1981b) Sexual maturation in triploid male plaice (Pleuronectes platessa) and plaice $\times$ flounder (Platichthys flesus) hybrids. J Fish Biol 19:499-508. https://doi.org/10. 1111/j.1095-8649.1981.tb03818.x

Liu H, Wu Z, Zhu X et al (2018) Comparative performance of growth, vertebral structure and muscle composition in diploid and triploid paralichthys olivaceus. J Fish Dis 41:1495-1504. https://doi.org/10.1111/jfd.12846

Ludwig A, Belfiore NM, Pitra C et al (2001) Genome duplication events and functional reduction of ploidy levels in sturgeon (Acipenser, Huso and Scaphirhynchus). Genetics 158:1203-1215

Machado SN, Ferreira-Neto M, Bakkali M et al (2012) Natural triploidy and $\mathrm{B}$ chromosomes in Astyanax scabripinnis (characiformes, characidae): a new occurrence. Caryologia 65:40-46. https://doi.org/10.1080/00087114.2012.678086

Maistro EL, Lúcia Dias A, Foresti F et al (1994) Natural triploidy in Astyanax scabripinnis (Pisces, Characidae) and simultaneous occurrence of macro B-chromosomes. Caryologia 47:233-239. https://doi.org/10.1080/ 00087114.1994.10797301

McQuown E, Gall GAE, May B (2002) Characterization and inheritance of six microsatellite loci in lake sturgeon. Trans Am Fish Soc 131:299-307

Meyer A, Van De Peer Y (2005) From 2R to 3R: Evidence for a fish-specific genome duplication (FSGD). BioEssays 27:937-945. https://doi.org/10.1002/bies.20293

Molina WF, Margarido VP, Galetti PM Jr (2007) Natural triploidy in Leporinus cf. elongatus bearing sex chromosomes. Genet Mol Biol 30:567-569. https://doi.org/10. 1590/s1415-47572007000400010

Morelli S, Bertollo LAC, Moreira FO (1983) Cytogenetic considerations on the genus Astyanax (Pisces, Characidae). II Occurrence of natural triploidy. Caryologia 36:245-250. https://doi.org/10.1080/00087114.1983.10797665

Nuez-Ortín WG, Carter CG, Wilson R et al (2017) Triploid Atlantic salmon shows similar performance, fatty acid composition and proteome response to diploids during early freshwater rearing. Comp Biochem Physiol-Part D Genom Proteom 22:67-77. https://doi.org/10.1016/j.cbd. 2017.02.005

Ojima Y, Takai A (1979) The occurrence of spontaneous polyploid Japanese common Loach, Misgurnus anguicaudatus. Proc Jpn Acad 55:487-491

Ojolick EJ, Cusack R, Benfey TJ, Kerr SR (1995) Survival and growth of all-female diploid and triploid rainbow trout (Oncorhynchus mykiss) reared at chronic high temperature. Aquaculture 131:177-187. https://doi.org/10.1016/00448486(94)00338-O

Omoto N, Maebayashi M, Adachi S et al (2005) The influence of oocyte maturational stage on hatching and triploidy rates in hybrid (bester) sturgeon, Huso huso $\times$ Acipneser ruthenus. Aquaculture 245:287-294. https://doi.org/10.1016/j. aquaculture.2004.11.008

Omoto N, Maebayashi M, Adachi S et al (2002) Histological observations of gonadal development in gynogenetic diploids and triploids of a hybrid. Fish Sci 68:1271-1272

Ozerov MY, Lumme J, Päkk P et al (2010) High Gyrodactylus salaris infection rate in triploid Atlantic salmon Salmo salar. Dis Aquat Organ 91:129-136. https://doi.org/10. 3354/dao02242

Pandian TJ, Koteeswaran R (1999) Natural occurrence of monoploids and polyploids in the Indian catfish, Heteropneustes fossilis. Curr Sci 76:1134-1137

Peng Z, Ludwig A, Wang D et al (2007) Age and biogeography of major clades in sturgeons and paddlefishes (Pisces: Acipenseriformes). Mol Phylogenet Evol 42:854-862. https://doi.org/10.1016/j.ympev.2006.09.008

Pereira dos Santos M, Ferreira do Nascimento N, Shigueki Yasui G et al (2018) Short-term storage of the oocytes affects the ploidy status in the yellowtail tetra Astyanax altiparanae. Zygote 26:89-98. https://doi.org/10.1017/ S0967199417000739

Peruzzi S, Rudolfsen G, Primicerio R et al (2009) Milt characteristics of diploid and triploid Atlantic cod (Gadus morhua L.). Aquac Res 40:1160-1169. https://doi.org/10.1111/j. 1365-2109.2009.02212.x

Piferrer F, Beaumont A, Falguière J-C et al (2009) Polyploid fish and shellfish: production, biology and applications to aquaculture for performance improvement and genetic containment. Aquaculture 293:125-156. https://doi.org/ 10.1016/j.aquaculture.2009.04.036

Pšenička M, Kašpar V, Rodina M et al (2011) Comparative study on ultrastructure and motility parameters of spermatozoa of tetraploid and hexaploid Siberian sturgeon Acipenser baerii. J Appl Ichthyol 27:683-686

Psenicka M, Rodina M, Linhart O (2010) Ultrastructural study on the fertilisation process in sturgeon (Acipenser), function of acrosome and prevention of polyspermy. Anim Reprod Sci 117:147-154. https://doi.org/10.1016/j. anireprosci.2009.03.013

Pyatskowit JD, Krueger CC, Kincaid HL, May B (2001) Inheritance of microsatellite loci in the polyploid lake sturgeon (Acipenser fulvescens). Genome 44:185-191. https://doi.org/10.1139/gen-44-2-185

Rodzen JA, May B (2002) Inheritance of microsatellite loci in the white sturgeon (Acipenser transmontanus). Genome 45:1064-1076. https://doi.org/10.1139/G02-083 
Romanenko SA, Biltueva LS, Serdyukova NA et al (2015) Segmental paleotetraploidy revealed in sterlet (Acipenser ruthenus) genome by chromosome painting. Mol Cytogenet 8:90. https://doi.org/10.1186/s13039-015-0194-8

Sacobie CFD, Burke HA, Lall SP, Benfey TJ (2016) The effect of dietary energy level on growth and nutrient utilization by juvenile diploid and triploid brook charr, Salvelinus fontinalis. Aquac Nutr 22:1091-1100. https://doi.org/10. 1111/anu.12347

Saranyan PV, Ross NW, Benfey TJ (2017) Erythrocyte heat shock protein responses to chronic (in vivo) and acute (in vitro) temperature challenge in diploid and triploid salmonids. Comp Biochem Physiol-Part A Mol Integr Physiol 206:95-104. https://doi.org/10.1016/j.cbpa.2017. 01.007

Schreier A, Fiske A, Van Eenennaam J, Hubálek M (2020) 2019 genetic diversity monitoring and development of parentage based tagging for white sturgeon in the Kootenai Tribe of Idaho native fish conservation aquaculture program and study of $10 \mathrm{~N}$ reproductive development. Technical report to the Kootenai Tribe of Idaho, Bonners Ferry, ID, p 15

Schreier AD, May B, Gille DA (2013) Incidence of spontaneous autopolyploidy in cultured populations of white sturgeon, Acipenser transmontanus. Aquaculture 416-417:141-145

Scott MA, Dhillon RS, Schulte PM, Richards JG (2014) Physiology and performance of wild and domestic strains of diploid and triploid rainbow trout (Oncorhynchus mykiss) in response to environmental challenges. Can J Fish Aquat Sci 72:125-134. https://doi.org/10.1139/cjfas-2013-0450

Small SA, Benfey TJ (1987) Cell size in triploid salmon. J Exp Zool 241:339-342. https://doi.org/10.1002/jez. 1402410309

Smith EM, Gregory TR (2009) Patterns of genome size diversity in the ray-finned fishes. Hydrobiologia 625:1-25. https:// doi.org/10.1007/s10750-009-9724-x

Symonová R, Flajšhans M, Sember A et al (2013) Molecular cytogenetics in artificial hybrid and highly polyploid sturgeons: an evolutionary story narrated by repetitive sequences. Cytogenet Genome Res. https://doi.org/10. $1159 / 000354882$

Taylor JF, Bozzolla P, Frenzl B et al (2014) Triploid Atlantic salmon growth is negatively affected by communal ploidy rearing during seawater grow-out in tanks. Aquaculture 432:163-174. https://doi.org/10.1016/j.aquaculture.2014. 05.014

Taylor JF, Preston AC, Guy D, Migaud H (2011) Ploidy effects on hatchery survival, deformities, and performance in Atlantic salmon (Salmo salar). Aquaculture 315:61-68. https://doi.org/10.1016/j.aquaculture.2010.11.029

Thorgaard GH, Gall GA (1979) Adult triploids in a rainbow trout family. Genetics 93:961-973

Thorgaard GH, Rabinovitch PS, Shen MW et al (1982) Triploid rainbow trout identified by flow cytometry. Aquaculture 29:305-309. https://doi.org/10.1016/00448486(82)90144-2

Thorstensen M, Bates P, Lepla K, Schreier A (2019) To breed or not to breed? Maintaining genetic diversity in white sturgeon supplementation programs. Conserv Genet 20:997-1007. https://doi.org/10.1007/s10592-019-011904
Tsuda JR, de Moraes VP, Giuliano-Caetano L, Dias AL (2010) Occurrence of natural triploidy in Rhamdia quelen (Siluriformes, Heptapteridae). Genet Mol Res 9:1929-1935. https://doi.org/10.4238/vol9-3gmr949

Ueda BYT, Sawada M, Kobayashi J (1987) Cytogenetical characteristics of the embryos between diploid female and triploid male in rainbow trout. Jpn J Genet 62:461-465

Ueda T, Ojima Y, Kato T, Fukuda Y (1983) Chromosomal polymorphisms in the rainbow trout (Salmo gairdneri). Proc Japan Acad Ser B Phys Biol Sci 59:168-171. https:// doi.org/10.2183/pjab.59.168

Utsunomia R, Pansonato Alves JC, Paiva LRS et al (2014) Genetic differentiation among distinct karyomorphs of the wolf fish Hoplias malabaricus species complex (Characiformes, Erythrinidae) and report of unusual hybridization with natural triploidy. J Fish Biol 85:1682-1692. https:// doi.org/10.1111/jfb. 12526

Van Eenennaam AL, Murray JD, Medrano JF (1998a) Synaptonemal complex analysis in spermatocytes of white sturgeon, Acipenser transmontanus Richardson (Pisces, Acipenseridae), a fish with a very high chromosome number. Genome 41:51-61. https://doi.org/10.1139/gen41-1-51

Van Eenennaam AL, Murray JD, Medrano JF (1998b) Mitotic analysis of the North American white sturgeon, Acipenser transmontanus Richardson (Pisces, Acipenseridae), a fish with a very high chromosome number. Genome 41:266-271. https://doi.org/10.1139/gen-41-2-266

Van Eenennaam AL, Van Eenennaam JP, Medrano JF, Doroshov SI (1996) Rapid verification of meiotic gynogenesis and polyploidy in white sturgeon (Acipenser transmontanus Richardson). Aquaculture 147:177-189

Van Eenennaam JP, Chapman FA, Jarvis PL (2004) Aquaculture. In: LeBreton GTO, Beamish FWH, McKinley RS (eds) Sturgeons and Paddlefish of North America. Fish and Fisheries Series, vol 27. Kluwer Academic Publishers, Dordrecht, pp 277-311

Van Eenennaam JP, Fiske AJ, Leal MJ et al (2020) Mechanical shock during egg de-adhesion and post-ovulatory ageing contribute to spontaneous autopolyploidy in white sturgeon culture (Acipenser transmontanus). Aquaculture 515:734530. https://doi.org/10.1016/j.aquaculture.2019. 734530

Várkonyi E, Bercsényi M, Ozouf-Costaz C, Billard R (1998) Chromosomal and morphological abnormalities caused by oocyte ageing in Silurus glanis. J Fish Biol 52:899-906. https://doi.org/10.1111/j.1095-8649.1998.tb00590.x

Vasil'ev VP, Vasil'eva ED, Shedko SV, Novomodny GV (2010) How many times has polyploidization occurred during acipenserid evolution? New data on the karyotypes of sturgeons (Acipenseridae, Actinopterygii) from the Russian Far East. J Ichthyol 50:950-959. https://doi.org/10. 1134/S0032945210100048

Venere PC, Galetti Junior PM (1985) Natural triploidy and chromsome B in the fish Curimata modesta (Curimatidae, Characiformes). Braz J Genet 8:681-687

Walters C (1986) Adaptive management of renewable resources. MacMillan Publishers Ltd, Basingstoke

Welsh A, May B (2006) Development and standardization of disomic microsatellite markers for lake sturgeon genetic 
studies. J Appl Ichthyol 22:337-344. https://doi.org/10. 1111/j.1439-0426.2006.00814.x

Witeska M (2013) Erythrocytes in teleost fishes: a review. Zool Ecol 23:275-281. https://doi.org/10.1080/21658005.2013. 846963

Withler RE, Beacham TD, Solar II, Donaldson EM (1995) Freshwater growth, smolting, and marine survival and growth of diploid and triploid coho salmon (Oncorhynchus kisutch). Aquaculture 136:91-107. https://doi.org/10.1016/ 0044-8486(95)01036-X

Wolters WR, Chrisman CL, Libey GS (1982) Erythrocyte nuclear measurements of diploid and triploid channel catfish, Ictalurus punctatus (Rafinesque). J Fish Biol 20:253-258. https://doi.org/10.1111/j.1095-8649.1982. tb04706.x

Zhang Q, Arai K (1999) Distribution and reproductive capacity of natural triploid individuals and occurrence of unreduced eggs as a cause of polyploidization in the loach, Misgurnus anguillicaudatus. Ichthyol Res 46:153-161

Zhou H, Fujimoto T, Adachi S et al (2011) Genome size variation estimated by flow cytometry in Acipenser mikadoi,
Huso dauricus in relation to other species of Acipenseriformes. J Appl Ichthyol 27:484-491. https://doi.org/10. 1111/j.1439-0426.2010.01648.x

Zhou H, Fujimoto T, Adachi S et al (2013) Molecular cytogenetic study on the ploidy status in Acipenser mikadoi. J Appl Ichthyol 29:51-55. https://doi.org/10.1111/jai. 12109

Schreier A and Van Eenennaam JP (2016) Ploidy analysis of captive Atlantic sturgeon. Technical report to the US Fish and Wildlife Service, NortheastFishery Center, Lamar, PA, $5 \mathrm{pp}$

Schreier A, JP Van Eenennaam, AE Todgham, FS Conte, M Webb, and S Young (2019) Determining causes, costs, and benefits of triploidization toimprove sturgeon caviar production. Termination report to the Western Regional Aquaculture Center, Seattle, WA, 35 pp

Publisher's Note Springer Nature remains neutral with regard to jurisdictional claims in published maps and institutional affiliations. 